\title{
THE DRIVERS OF THE COMPETITIVENESS OF FIRMS IN THE NON-FINANCIAL SECTOR: EVIDENCE FROM NIGERIA
}

\author{
Fatai Abiodun Atanda ${ }^{*_{1}}$ and Florence Olubunmi Osemene ${ }^{2}$ \\ ${ }^{1}$ Department of Accounting, University of Ibadan, Nigeria \\ ${ }^{2}$ Department of Accounting and Finance, University of Ilorin, Nigeria
}

This study examines the key determinants of the competitiveness of firms in Nigeria. It draws the firmlevel (i.e. firm-specific characteristics) data and macro-data (environmental factors) from the annual reports and accounts of non-financial listed firms and the Statistical Bulletin of the Central Bank of Nigeria, respectively. In addition, it employs descriptive, inferential and econometric tools to analyze the data. The results reveal that the age of a firm, its productive assets, profitability and the capital expenditure ratio of the government enhanced the competitiveness of high-competition firms, on the one hand, while the high cost of finance hindered it, on the other. However, profitability, business risk, the size of a firm and inflation contributed to the competitiveness of low-competition firms, on the one hand, while sales growth and employees' capacity reduced it, on the other. It was concluded that both firm-specific and environmental factors played the beneficial and detrimental roles when the level of the competitiveness achieved by the Nigerian non-financial listed firms is concerned. Thus, the policy implications of these results were discussed.

Keywords: high-competition firm, low-competition firm, value creation, firm-specific factor, environmental factor

\section{JEL Classification: M41, G32}

\section{INTRODUCTION}

The effect of globalization and the need to meet the increasing varieties of customer needs require that contemporary businesses should achieve a competitive advantage. In addition, the number of the companies

* Correspondence to: F. A. Atanda, Department of Accounting, University of Ibadan, Nigeria;

e-mail: atanda2001uk@yahoo.co.uk that folded up during and after the 2008 economic crisis and the 2015 economic meltdown signaled to the surviving ones the need to increase their level of competitiveness in their industrial sectors, which then led us to the question, 'How can firms be made competitive?' M. Porter (1999) strives to answer this question by positing that being competitive requires businesses to develop an increasing interest in the key strategic management processes and operations, 
which means that businesses should make the competition-related decisions that may lead to the creation of increased economic value. A business creates value when it generates wealth from economic activities, transforming inputs into outputs. Therefore, value is referred to as the difference between an output value and an input value (Booth, 1998), which can be either positive, when a firm is able to cover the actual and opportunity costs of the purchased inputs or components used to generate sales revenue, or negative, when a firm is unable to cover its input costs.

Although Nigerian quoted firms operate within the same economic conditions, some of them create positive economic value (EVA) and some create negative value (Atanda \& Asaolu, 2015). In addition, some of them create higher economic value from a given level of economic activities or sales revenue than others, while some destroy it. These make some of them high-competition (HC) and low-competition (LC) firms in value creation. The differences in the levels of competitiveness may appear as a result of their differing capacities, capabilities and resources, which also vary from time to time. This is because the ability of a firm to develop and deploy its capabilities and talents far more effectively than its competitors helps it to achieve world-class competitiveness (Smith, 1995). Firms' capabilities, therefore, revolve around internal factors or firm-specific characteristics, such as the organizational structure, productive assets, growth and risk.

According to M. Porter (1999), competitiveness revolves around a combination of a country's conditions and a firm's strategy to seize opportunities provided by those conditions. This means that the economic conditions of a country may bring about many challenges and opportunities at the firm, industry and country levels and shaken confidence in businesses (Ambastha \& Momaya, 2006). It also means that environmental conditions, such as natural resources, infrastructures, government policies (fiscal and monetary) and the level of economic growth, may also have an influence on the competitiveness of a firm. Therefore, in order for a firm to be competitive in value creation, it should succeed in dealing with challenges and limitations posed by the environment, market developments and the economic conditions of a country.

Previous studies established the fact that quoted firms in Nigeria had a potential for value creation (Akalu, 2002; Asogwa, 2009; F. A. Atanda and T. Asaolu, 2015). F. A. Atanda and T. Asaolu (2015) provided the empirical evidence that showed that, in recent times, companies had created an economic value greater than in previous periods, in real terms. However, there is unarguably a lack of ample empirical evidence of the reasons why some of the firms were highly competitive in value creation while others were not, although operating under the same environmental, market and economic conditions. That pointed to the specific business research problem of how the firms could be made highly competitive in creating economic value. This study examines the key factors that have contributed to the level of the competitiveness achieved by non-financial quoted firms in Nigeria. The fact that firm-specific and environmental factors do not have significant effects on the level of the competitiveness achieved by $\mathrm{HC}$ firms and LC firms in Nigeria is hypothesized herein.

The main contributions of this paper are articulated in the following: first, non-financial listed firms operate within the same economy, with a high tendency to experience similar shocks from environmental variables, such as inflation, interest rates, government policies and foreign-exchange rates, with similar consequences for their performances. However, the available data show that the firms differ greatly in terms of the level of competitiveness, efficiency in resource utilization (profitability), employees' capacity and risk appetite (business risk), which made them be categorized into high-competition and lowcompetition firms; second, while acknowledging a few notable studies, namely those by A. Ambastha and K. Momaya (2006), P. Liargovas and K. Skandalis (2008), B. Navaretti, M. Bugamelli, F. Schivadi, C. Altomonte, D. Horgos and D. Maggiani, (2011), M. A. Afridi and M. E. Javaid (2015), E. Akben-Selcuk (2016), A. Onakoya (2018), the issue of unequal meanings, factors (and their impacts), as well as different adopted methodologies, needs further 
examination in terms of measurement and modelling. Competitiveness is a concept not well-understood despite its widespread usage (Onyemenam, 2014) and a complete competitiveness analysis must define how it is measured and identify the most important factors that influence it (Lall, 2001). Thus, unlike in the previous studies, where the absolute figures of sales, earnings and market value were used, this present study follows the Assets-Processes-Performance (APP) framework to measure the competitiveness of a firm as a proportion of EVA to sales revenue, relative to other firms. This is due to the superiority of EVA over accounting metrics (Booth, 1998). In addition, the Generalized Method of Moments (GMM) is employed in order to estimate the linear regression model due to the outcome of the Partial Autocorrelation (PAC) test conducted on the time series properties of the dependent variable (the competitiveness of a firm) by using the Box-Jenkins Q-statistic method; third, this study adds to the existing literature on the competitiveness of firms, namely A. Ambastha and K. Momaya (2006), P. Liagovas and K. Skandalis (2008), Navaretti et al (2011), M. A. Afridi and M. E. Javaid (2015), E. Akben-Selcuk (2016), by conducting a comprehensive and robust analysis, simultaneously accounting for the firm-specific factors such as the size of a firm, its age (in order to measure the reputation of a firm), employees' capacity, liquidity, leverage, risk, growth, productive assets and profitability, as well as environmental factors, such as inflation, the cost of finance (interest rates) and developments in the labor market. This is consistent with the position of the RBV theory that a firm's internal environment is critical to the strategic actions that will be undertaken so as to achieve a competitive advantage and the argument of L. Porter, E. Lawler and J. Hackman (1975) that only the organizations that are able to deal with the demands of their environment or environmental influences will achieve the best.

The rest of the paper is organized into four sections: Section Two deals with a review of theoretical and empirical studies; Section Three covers the research methods; Section Four provides the results of the data analysis, and Section Five gives the conclusion of the study.

\section{THEORETICAL AND EMPIRICAL REVIEWS}

The theory of the Resource-Based View (RBV) and the Assets-Processes-Performance (APP) framework form the bedrock of this study. The RBV considers a firm as a collection of unique resources and capabilities, which provide the basis for the strategies that are the primary sources of earnings. It posits that a firm with a relatively small amount of resources, but with a high ambition, may leverage their resources so as to achieve a greater output for its smaller inputs and that, with increased effectiveness, the resources that will be available to the firm may be larger (Hamel \& Prahalad, 1993). The theory is grounded in the perspective that a firm's internal environment (in terms of its resources and capabilities) is more critical to the determination of strategic actions to undertake in order to achieve a sustainable competitive advantage in its market and industry. However, this is not to say that the external environment is not important. This is because there are some environmental influences that a firm should deal with and only organizations whose internal features match the demands of their environment best will achieve the best (Porter et al, 1975).

In fact, changes inside and outside a firm put more responsibilities on its managers regarding the manner in which the problem of instability in environmental variables, such as developments in the financial market, inflation and government policies, will be addressed. Instead of accumulating the resources needed to implement the strategies dictated by external environmental conditions, the theory expects that a firm's unique resources and capabilities will provide the basis for a strategy, and the strategy will allow the firm to best exploit its core competencies relative to opportunities in the environment (Hamel \& Prahalad, 1993). In addition, the theory expects a firm to manage its resources and capabilities in its pursuit of aboveaverage returns and implement the strategies that can help achieve goals in an efficient manner. It must be noted that resources themselves confer no value to a firm. It is only when they are put into a productive use that value can be created. Therefore, this means that differences in firms primarily driven by their unique resources and capabilities will contribute to a firm's ability to be highly competitive over time. The 
firms that face similar industrial or market conditions are ordinarily expected to exhibit a certain degree of similarity in performance. Due to differences in internal structures, how resources are combined and capacities to utilize resources in the most competitive ways, a great divergence in firms' performances may be detected. This is because not all the resources that a firm has access to are strategically relevant (Barney, 1991). Some resources may actually prevent a firm from conceiving and implementing valuable strategies, whereas an efficient combination of resources may lead to the competencies and strategies that may reduce inefficiency. The major limitation of the RBV is that it does not guide policy makers how to integrate a strategy with competitiveness.

However, the Assets-Processes-Performance (APP) framework, which integrates resources with performance through processes, provides a better tool for the integration of a strategy with the competitiveness of a firm (Shee, 2002). The framework provides managers with the means of the categorization of the sources of competitiveness, their relevance and performance. Under the 'Assets', the sources of the competitiveness of a firm include brands, reputation, human resources and technology. However, the sources include a strategy, innovations, relationship management, manufacturing and marketing under the 'Processes', whereas under the 'Performance', they include customer satisfaction, value creation, a market share and productivity (Ambastha \& Momaya, 2006). This means that competitiveness requires a combination of the resources and the process used to transform the resources so as to achieve economic gains. Some firms are more competitive than others, due to their varied internal factors, such as strategies, structures, competencies, resources and capacities, in order to innovate in the areas such as financing, resources allocation and production (Prahalad \& Hamel, 1990). At the firm level, therefore, to be competitive means to create higher economic value from product and service designing, production and marketing.

The literature review showed that finance, assets, revenue growth opportunities and several characteristics of a firm influenced the competitiveness of a firm. In fact, the value of a firm changes over time as a result of changes in the size of the company, i.e. when the company changes the quantity of the resources used without changing the efficiency of the resources used (Lieberman \& Balasubramanian, 2007). D. Mouldi, H. Abdelaziz and H. Ilehmi (2011) found that the size positively and significantly affected the value of a firm measured by return on assets and return on equity. A significant positive effect of the size of a firm measured by the natural logarithm of the firm's total assets on value creation measured by economic value added (EVA) and Free Cash Flows (FCF) was also found by F. A. Atanda (2014). In addition, while exploring the relationship between the characteristics of a firm and the financial performance of the quoted manufacturing firms operating in the consumer goods sector of the Nigerian economy, C. Egbunike and C. Okerekeoti (2018) found a significant effect of the characteristics of a firm, such as the size, leverage and liquidity, on return on investment.

Growth is an important goal for the largest number of corporations because, according to C. Daily and M. Dollinger (1993), it is only through growth that professional managers can find new opportunities. However, F. A. Atanda (2014) found a weak, positive and insignificant effect of sales growth on EVA and a significant positive effect of sales growth on a free cashflow. Differences in age may also account for the reason why some companies are more competitive in creating value than others. D. Mouldi et al (2011) found that age had a positive and significant effect on a firm's performance, because old firms were able to build their reputation in comparison with young ones. Risk can be defined as the probability that actual returns will deviate from expected returns (McConaughy, Matthews \& Fialko, 2001). This is often measured by using the standard deviation of returns. In addition, risk can be measured as a ratio of external (i.e. debts) to internal (equity) financing or the extent to which a firm's assets are financed by externally sourced funds. This showed that there were two categories of risk:

- business risk, which cannot be diversified, and

- finance risk, which can be diversified. 
The debt capacity was used by J. Jorgensen (1967), where it was found that a higher debt led to a higher capacity to embark on the investments that enhanced value. So, a higher finance risk led to higher investments, which might lead to higher returns, ceteris paribus. While the significant positive effect of finance risk on a firm's performance was found by E. Laitinen (2008) and R. Asogwa (2009), the result obtained by F. A. Atanda (2014) regarding the effect of business risk on EVA was insignificant and weak, although positive. In addition, J. Samuel, M. Pulimi, M. L. Paul, A. Maurya, N. Chandrasekaran and A. Mukherjee (2013) examine the impact of long-term debts on the value of the firms listed on the Ghana Stock Exchange (GSE), and concludes that the variable has a statistically significant impact on the value of a firm.

Moreover, P. Liargovas and K. Skandalis (2008) found a significant positive relationship between the number of employees and the competitiveness of a firm measured by the profitability of Greek companies. B. Navaretti et al (2011) also found a significant positive relationship between the intensity of the skills of the workforce and the competitiveness of a firm by using a combination of questionnaire survey data and the firm-level financial data on European firms. Asset tangibility shows the structure of the assets employed by a company. The companies engaged in production and services have a different asset structure, which leads to differences in the degree of replication, routine and the task variety (Abernethy \& Lillis, 1995), which, therefore, may result in different value creation potentials. Moreover, a stable environment was regarded as important for a firm's performance and the competitiveness of an economy. In fact, there are pieces of evidence that businesses are best conducted in an environment of stability with the minimum level of uncertainty (A. Adenikinju, 2005). The variables used as proxies in many studies included a gross domestic product, inflation, foreign exchange rates, developments in (labor and financial) markets, interest rates, physical infrastructures and government regulations and policies (Odior, 2013; Atanda, Asaolu \& Oyerinde, 2015; Egbunike \& Okerekeoti, 2018; Onakoya, 2018).
According to X. Z. Zhang and S. S. Mirza (2015), inflation is a very important factor for a country's stable growth and any increase in the inflation rate may bring uncertainty to the economy. E. Odior (2013) employed the cointegrating equation of the Vector Error Correction Model (VECM) so as to examine the impact of the macroeconomic variables such as interest rates on the productivity of manufacturing firms in Nigeria. The author found a negative effect of the cost of borrowing, which was due to the high interest rates on the output growth both in the short run and in the long run. However, using the Johansen cointegration test, A. Onakoya (2018) found no short-term effect of the exchange rates and the gross domestic product on the manufacturing output in Nigeria. In addition, C. Egbunike and C. Okerekeoti (2018) found no significant effect for the interest rate and the exchange rate, but did find a significant effect for the inflation rate and the gross domestic product growth rate on the return on investment of some selected manufacturing firms listed on the Nigerian Stock Exchange. F. A. Atanda et al (2015) found a significant negative effect of inflation on the value created by the Nigerian quoted firms during the period from 2001-2012. Using the generalized method of the moments estimation technique, the authors also found significant positive effects of exchange rates, interest rates, the gross domestic product growth and developments in the labor market on value creation. It is, however, unknown whether these variables have significant effects on the level of the competitiveness achieved by firms.

The foregoing shows that the financial performance of both financial and non-financial firms in Nigeria, as well as the factors that determined it, has been done research into, paying little or no attention at all on the competitiveness of the firms. Despite the recorded performance, some of the firms folded up as a result of the economic crises experienced in the past, whereas those that had survived made decisions related to competition, which led to the creation of increased economic value. There is, therefore, the need to extend the knowledge by capturing the firmspecific and environmental factors that contribute 
to the competitiveness level achieved by firms. The consideration and a robust analysis of the key factors will lead to the policy issues that can be used to improve the competitiveness of firms amongst the non-financial listed firms in Nigeria.

\section{METHODOLOGY}

The panel data collected from the annual reports and accounts of the 68 non-financial listed firms in Nigeria and the time series data collected from the annual Statistical Bulletin of the Central Bank of Nigeria, the 2017 edition, during the period from 1995-2017 were employed in this study. The sample was divided into the two groups of an equal size: the LC and HC firms. A firm characterized by an average competitiveness (i.e. the proportion of EVA to sales revenue relative to other firms) greater than the overall average for the sample was considered as an HC firm; otherwise, it was categorized as an LC firm. Although correlation analysis helps identify the exogenous variables in the model, it does not provide guidance to the process that generated the dependent variable, i.e. the competitiveness of a firm. Therefore, the time series properties of the competitiveness of firms were explored by using the Box-Jenkins Q-statistic method. The autocorrelation and partial autocorrelation functions were plotted to determine whether the variable followed the autoregressive (AR) or moving average (MA) or both (ARMA) processes and the period(s). The lagged dependent variable was added to the right-hand side of the model, due to the autoregression of the variable at the lag order AR(n). The effect of the firm-specific and environmental factors on the competitiveness of firms is modeled by using the following linear equation:

$$
\begin{aligned}
& \text { FMC }_{i t}=\alpha+\beta_{1} \operatorname{InAGE}_{i t}+\beta_{2} \mathrm{COF}_{i t}+\beta_{3} \operatorname{InFRX}_{i t}+ \\
& \beta_{4} C A R_{i t}+\beta_{5} \operatorname{InSZE}_{i t}+\beta_{6} L E V_{1, i t}+\beta_{7} \mathrm{GRW}_{i t}+ \\
& \beta_{8} R S K_{i t}+\beta_{9} \operatorname{LIQ}_{i t}+\beta_{10} A S T_{i t}+\beta_{11} \operatorname{InNOE}_{i t}+ \\
& \beta_{12} \mathrm{PRT}_{i t}+\beta_{13} I_{i t}+\beta_{14} \mathrm{LBM}_{i t}+ \\
& \beta_{j} \sum_{j=1}^{n} \mathrm{FMC}_{i, t-j}+\mu_{i t}
\end{aligned}
$$

where, FMC is the competitiveness of a firm $i$ at the time $t, A G E$ is the number of the years of being in operations from the date of incorporation for the firm $i$ at the time $t$, COF is the cost of financing for the firm $i$ at the time $t, F R X$ is the prevailing foreign exchange rate for the firm $i$ at the time $t, C A R$ is the capital expenditure ratio of the government for the firm $i$ at the time $t, S Z E$ is the size of the firm $i$ at the time $t, L E V$ is the leverage for the firm $i$ at the time $t$, $G R W$ is the growth in sales for the firm $i$ at the time $t, R S K$ is the risk for the firm $i$ at the time $t, L I Q$ is the liquidity ratio of the firm $i$ at the time $t, A S T$ is the productive asset for the firm $i$ at the time $t, N O E$ is the number of the employees in the firm $i$ at the time $t$, PRT is profitability (i.e. operating efficiency) for the firm $i$ at the time $t$, INF is the inflation rate for the firm $i$ at the time $t, \mathrm{LBM}$ is the developments in the labor market for the firm $i$ at the time $t$, In is the natural logarithm sign, $\alpha$ is the constant, $\beta_{i}$ is the coefficients to be estimated for the explanatory variables and $\mu$ is the stochastic error term. The variables in the model are measured as shown in Table 1.

The variables were selected based on the elements identified in the RBV theory and the Assets-ProcessesPerformance framework, as well as in the findings of previous studies, such as P. Liargovas and $\mathrm{K}$. Skandalis (2008), E. Laitinen (2008), R. Asogwa (2009), B. Navaretti et al (2011), T. Korankye and R. Adarquah (2013), F. A. Atanda (2014), F. A. Atanda et al (2015), M. A. Afridi and M. E. Javaid (2015), C. Egbunike and C. Okerekeoti (2018), A. Onakoya (2018). The dependent variable was the competitiveness of a firm, whereas the firm-specific and environmental factors were the explanatory variables. The following procedures were carried out in order to analyze the data: the descriptive techniques were used to examine the features typical of the data, the sampled firms, the LC firms and the HC firms. Subsequently, multiple correlation was used to test for any incidence of the multicollinearity problem in the explanatory variables. This was to ascertain if all the identified variables should be included in the regression model, without resulting in spurious estimates. In addition, the time series properties of the data were examined by performing a partial autocorrelation test by using the Box-Jenkins statistics to test for the endogeneity problem in the 
Table 1 The chart of variables and measurement

\begin{tabular}{|c|c|c|c|}
\hline Variable & A priori & Explanation & Measurement \\
\hline $\begin{array}{l}\text { Firm } \\
\text { Competitiveness } \\
\text { (FMC) }\end{array}$ & & $\begin{array}{l}\text { This is the ability of a firm to create economic } \\
\text { value from sales, relative to other firms. }\end{array}$ & $\begin{array}{l}\text { The ratio of value added (EVA) to sales } \\
\text { revenue. EVA is the difference between } \\
\text { the output value and the input value. }\end{array}$ \\
\hline Firm age (AGE) & + & $\begin{array}{l}\text { This is the number of the years which a firm has } \\
\text { been incorporated for. Older firms may benefit } \\
\text { from reputation and long-term relationships. }\end{array}$ & $\begin{array}{l}\text { The natural logarithm of the number of } \\
\text { the years a firm has been in operation. }\end{array}$ \\
\hline Size (SZE) & + & $\begin{array}{l}\text { This is the competitive power of a firm. Smaller } \\
\text { firms are more volatile and riskier than larger } \\
\text { ones. }\end{array}$ & $\begin{array}{l}\text { The natural logarithm of the total } \\
\text { assets of a firm. }\end{array}$ \\
\hline Leverage (LEV) & - & $\begin{array}{l}\text { The extent to which a firm uses borrowed } \\
\text { money. A highly leveraged firm is at the risk of } \\
\text { liquidation. }\end{array}$ & The debts-to-the total liabilities ratio. \\
\hline Growth (GRW) & + & $\begin{array}{l}\text { The movement of a firm from one } \\
\text { development phase to another. A high rate } \\
\text { signifies investment opportunities. }\end{array}$ & The rates of change in sales revenue. \\
\hline Risk (RSK) & $-1+$ & $\begin{array}{l}\text { This is a risk inherent in a business, which } \\
\text { cannot be diversified. It is the variability in } \\
\text { returns (EBDIT) of each firm. }\end{array}$ & $\begin{array}{l}\text { The standard deviation of earnings } \\
\text { before depreciation, interests and } \\
\text { taxes (EBDIT). }\end{array}$ \\
\hline Liquidity (LIQ) & + & $\begin{array}{l}\text { The rate at which short-term indebtedness is } \\
\text { settled promptly. High liquidity refers to the } \\
\text { ability to quickly convert assets into cash. }\end{array}$ & $\begin{array}{l}\text { The ratio of the current assets to the } \\
\text { current liabilities (the current ratio). }\end{array}$ \\
\hline $\begin{array}{l}\text { Productive Assets } \\
\text { (AST) }\end{array}$ & + & $\begin{array}{l}\text { This is the extent to which the total assets of a } \\
\text { firm are physical, tangible and productive. }\end{array}$ & $\begin{array}{l}\text { The ratio of the fixed assets to the } \\
\text { total assets. }\end{array}$ \\
\hline $\begin{array}{l}\text { The employee } \\
\text { capacity (NOE) }\end{array}$ & + & $\begin{array}{l}\text { The total number of employees in a firm at a } \\
\text { point in time. }\end{array}$ & $\begin{array}{l}\text { The natural logarithm of the number of } \\
\text { employees. }\end{array}$ \\
\hline Profitability (PRT) & + & $\begin{array}{l}\text { The efficiency with which a firm uses its assets } \\
\text { to generate returns. }\end{array}$ & $\begin{array}{l}\text { The ratio of the EBIDT to sales } \\
\text { revenue. }\end{array}$ \\
\hline $\begin{array}{l}\text { The capital } \\
\text { expenditure of the } \\
\text { government (CAR) }\end{array}$ & + & $\begin{array}{l}\text { The economic infrastructures available in the } \\
\text { economy. }\end{array}$ & $\begin{array}{l}\text { The capital expenditure ofte } \\
\text { government as a proportion of the } \\
\text { GDP. }\end{array}$ \\
\hline Inflation (INF) & $+/-$ & Changes in price levels. & Prevailing inflation rates. \\
\hline $\begin{array}{l}\text { Developments in } \\
\text { the labor market } \\
\text { (LBM) }\end{array}$ & + & $\begin{array}{l}\text { Change of the labour force conpensation in the } \\
\text { economy. }\end{array}$ & $\begin{array}{l}\text { A conpensation paid to labour force as } \\
\text { a proportion of the GDP. }\end{array}$ \\
\hline $\begin{array}{l}\text { The cost of finance } \\
\text { (COF) }\end{array}$ & - & $\begin{array}{l}\text { The cost of servicing long-term debts } \\
\text { contracted by a firm. A high cost may deter } \\
\text { investments and reduce the income of a firm. }\end{array}$ & $\begin{array}{l}\text { Prevailing interest rates in the } \\
\text { economy. }\end{array}$ \\
\hline $\begin{array}{l}\text { The foreign } \\
\text { exchange policy } \\
(F R X)\end{array}$ & - & $\begin{array}{l}\text { This is the stance of the government on a } \\
\text { foreign-exchange market. A high rate may } \\
\text { increase costs and reduce the income of a firm. }\end{array}$ & $\begin{array}{l}\text { The natural logarithm of the prevailing } \\
\text { foreign-exchange rates. }\end{array}$ \\
\hline
\end{tabular}


dependent variable (the competitiveness of a firm) and the unit root tests using the four criteria (LevinLevin-Chu, Im-Pesaran-Shin, Augumented DickeyFuller and Philip-Peron) to determine the estimation technique appropriate for the data and the specified model. Since this study considered a large number of the explanatory variables, the multiple regression technique was found to be appropriate. The empirical results are presented in the tables and the same are discussed in the following section.

\section{EMPIRICAL RESULTS}

\section{Descriptive results}

Descriptive analysis showed the existence of the positive average value created during the periods, although the scattering of the economic values around the mean (i.e. the standard deviation) for the selected firms was high (Table 2). The HC firms engaged more employees than the LC firms, which means that the number of the employees might have contributed to the value creating potentials of the former comparing to the latter. The results further indicated the fact that the average age of the $\mathrm{HC}$ firms was lower compared to the LC firms. Also, there was a lower level of the revenue (sales) growth, the asset base and the productive assets for the HC firms compared to the LC firms. Therefore, there is the need to ascertain whether huge investments in tangible non-current assets necessarily lead to the high competitiveness of the firms, or not. Again, the LC firms were more liquid than the HC firms, which pointed to the fact that the former had more resources tied down in the current assets such as receivables and inventories than the latter. Moreover, there was an elevated level of the business risk of the $\mathrm{HC}$ firms compared to the average for the sample and the LC firms. This showed that there was the need for the empirical evidence of whether the firms that were aggressive in risk-taking were more competitive than the risk-averse firms. Also, using debts as a source of financing was higher in the LC firms than in the HC firms, which indicates that a highly-leveraged firm was likely to be a low performer than a low-leveraged firm. This might be due to the fact that a large proportion of the EVA created by the highly-leveraged firms will be used to service debts, which might threaten the sustainability of the firms even in the short run.

The data accounted for in Table 2 further provide information on the need to transform some of the explanatory variables in the regression model specified in this study, namely age, the employee capacity and the size of the firm. This was caused by the different means by which the variables were measured. The age of the firm was measured by the number of years and the employee capacity was measured by the number of employees, while the size of the firm was measured by the value of the company's total assets. These resulted in the high standard deviations obtained for the variables. Therefore, there is the need to reduce them to the same level as is the level of the other variables that were expressed in percentages. Consequently, the three explanatory variables were transformed by using a natural logarithm.

\section{Multicollinearity and the unit root test results}

Multicollinearity and the unit root test results are shown in the tables 3 and 4, respectively. The data in Table 3 show the low level of correlations among the explanatory variables pairwise, except for the relationship between CAR and the GDP; the FRX and INF, and the FRX and the LBM that were moderate, but not up to 0.8 benchmarked by Lewis-Beck (1993) for the existence of multicollinearity. However, high correlation levels between the GDP and the FRX $(r=0.805, P<.001)$, and between the GDP and the LBM $(r=0.917, P<.001)$ were found.

Similar results were obtained when the sample data were divided into the low- and high-competition firms. The correlations between the GDP and the FRX and between the GDP and the LBM for the highand low-competition firms, respectively, were 0.806 
Table 2 The descriptive statistics of the competitiveness of the firms and the firm-specific factors

\begin{tabular}{|c|c|c|c|c|c|c|c|c|c|c|}
\hline Statistics & AGE & AST & FMC & GRW & LEV & LIQ & NOE & PRT & RSK & SZE \\
\hline \multicolumn{11}{|l|}{ All Firms } \\
\hline Mean & 39.455 & 0.387 & 25.193 & 0.263 & 0.183 & 1.558 & 968.146 & 3.957 & $-1.73 \mathrm{E}-05$ & 10208.95 \\
\hline Standard dev. & 20.534 & 0.207 & 18.297 & 0.455 & 0.247 & 5.923 & 1381.29 & 24.996 & 3.118 & 30550.18 \\
\hline Maximum & 133.00 & 0.999 & 154.161 & 3.846 & 0.990 & 229.507 & 9475.00 & 66.198 & 58.512 & 515063.8 \\
\hline Minimum & 1.000 & 0.005 & -165.253 & -0.838 & -0.476 & -0.226 & 3.000 & -360.266 & -37.092 & 3.896 \\
\hline No. of obs. & 1535 & 1535 & 1535 & 1467 & 1535 & 1535 & 1535 & 1535 & 1535 & 1535 \\
\hline \multicolumn{11}{|c|}{ High-competition firms } \\
\hline Mean & 39.013 & 0.384 & 33.215 & 0.255 & 0.179 & 1.551 & 1122.34 & 8.270 & $-3.46 \mathrm{E}-05$ & 10071.87 \\
\hline Standard dev. & 22.018 & 0.209 & 15.084 & 0.428 & 0.235 & 1.068 & 1578.27 & 19.462 & 1.312 & 24608.02 \\
\hline Maximum & 133.000 & 0.999 & 154.16 & 3.113 & 0.987 & 15.247 & 9475.00 & 43.964 & 15.269 & 235701.20 \\
\hline Minimum & 1.000 & 0.005 & -55.058 & -0.838 & 0.000 & 0.002 & 3.000 & -150.58 & -6.312 & 3.896 \\
\hline No. of obs. & 769 & 769 & 769 & 735 & 769 & 769 & 769 & 769 & 769 & 769 \\
\hline \multicolumn{11}{|c|}{ Low-competition firms } \\
\hline Mean & 39.899 & 0.390 & 17.139 & 0.2720 & 0.186 & 1.565 & 813.363 & -0.372 & $4.41 \mathrm{E}-08$ & 10346.56 \\
\hline Standard Dev. & 18.932 & 0.205 & 17.698 & 0.481 & .258 & 8.319 & 1130.25 & 28.899 & 4.216 & 35546.30 \\
\hline Maximum & 115.000 & 0.999 & 77.725 & 3.846 & 0.990 & 229.507 & 5862.00 & 66.198 & 58.512 & 515063.8 \\
\hline Minimum & 4.000 & 0.006 & -165.253 & -0.791 & -0.476 & -0.226 & 9.000 & -360.266 & -37.092 & 5.563 \\
\hline No. of obs. & 766 & 766 & 766 & 732 & 766 & 766 & 766 & 766 & 766 & 766 \\
\hline
\end{tabular}

Source: Authors

and 0.919 ; and 0.854 and 0.916 at the $1 \%$ significance level. Since the issue of multicollinearity is very controversial, the results gave rise to the fact that the exogenous variable (the GDP) that demonstrated a high correlation with the other variables should not be included in the same estimated regression equation models. The linear regression expressed in Equation (1) was, therefore, remodeled accordingly by removing the GDP from the equation.

In addition, the data given in Table 4 show that the capital-expenditure ratio, developments in the labor market, the employee capacity and risk were integrated of order 1 , and needed to be included in the regression model at the first difference, whereas the other variables were integrated of zero or stationary at the level, hence being included at the level in the regression models. These results indicate the fact that the Ordinary Least Square (OLS) estimation method could not be used, but a higher-level estimation technique such as Autoregressive Distributed Lag (ARDL) should be used instead.

\section{Pre-estimation diagnostic results}

The results obtained from the Box-Jenkins Q-statistic test indicated that there was the endogeneity problem, because the competitiveness of a firm (measured by the proportion of economic value added to the sales revenue of a firm in relation to other firms) followed an autoregressive $\operatorname{AR}(2)$ function after two periods and for all firms (Table A1 in the Appendix). The variable also followed an autoregressive $\mathrm{AR}(1)$ function after one period for the HC firms and the LC firms, respectively, when the data were disaggregated (Tables A2 and A3 in the Appendix). The partial autocorrelation (PAC) column in the tables shows that the Q-statistic turns to less than 0.1 after the second period for the data of all the firms, and after the first period for the data of the $\mathrm{HC}$ firms and the LC firms, respectively. Therefore, a two-period lagged FMC was included among the explanatory variables in the model of the competitiveness of a firm for all the firms, whereas a one-period lagged FMC was included in the model for the high- and 
Table 3 The multiple correlation results

\begin{tabular}{|c|c|c|c|c|c|c|c|c|c|c|c|c|c|c|c|c|}
\hline Variable & AST & AGE & FMC & GRW & LEV & LIQ & NOE & PRT & RSK & SZE & CAR & COF & FRX & GDP & INF & LBM \\
\hline AST & 1.0000 & & & & & & & & & & & & & & & \\
\hline \multirow[t]{2}{*}{ AGE } & 0.1370 & 1.0000 & & & & & & & & & & & & & & \\
\hline & .000 & & & & & & & & & & & & & & & \\
\hline \multirow[t]{2}{*}{ FMC } & 0.0088 & -0.0597 & 1.0000 & & & & & & & & & & & & & \\
\hline & .731 & .019 & & & & & & & & & & & & & & \\
\hline \multirow[t]{2}{*}{ GRW } & -0.1173 & -0.1537 & 0.0827 & 1.0000 & & & & & & & & & & & & \\
\hline & .000 & .000 & .002 & & & & & & & & & & & & & \\
\hline \multirow[t]{2}{*}{ LEV } & -0.0126 & -0.1387 & 0.0292 & 0.1057 & 1.0000 & & & & & & & & & & & \\
\hline & .621 & .000 & .252 & .000 & & & & & & & & & & & & \\
\hline \multirow[t]{2}{*}{ LIQ } & -0.0392 & -0.0509 & 0.0305 & -0.0016 & 0.0021 & 1.0000 & & & & & & & & & & \\
\hline & .125 & .046 & .233 & .951 & .935 & & & & & & & & & & & \\
\hline \multirow[t]{2}{*}{ NOE } & 0.0723 & 0.3070 & 0.1040 & 0.0335 & -0.0552 & -0.0158 & 1.0000 & & & & & & & & & \\
\hline & .005 & .000 & .000 & .200 & .031 & .536 & & & & & & & & & & \\
\hline \multirow[t]{2}{*}{ PRT } & -0.2295 & -0.0269 & 0.6199 & 0.2147 & 0.0481 & 0.0509 & 0.1153 & 1.0000 & & & & & & & & \\
\hline & .000 & .293 & .000 & .000 & .060 & .046 & .000 & & & & & & & & & \\
\hline \multirow[t]{2}{*}{ RSK } & -0.0423 & 0.0675 & 0.2037 & 0.0462 & -0.0308 & -0.0114 & -0.0103 & 0.2901 & 1.0000 & & & & & & & \\
\hline & .098 & .008 & .000 & .077 & .228 & .656 & .687 & .000 & & & & & & & & \\
\hline \multirow[t]{2}{*}{ SZE } & 0.1485 & 0.1509 & 0.0075 & -0.0363 & -0.0457 & -0.0223 & 0.1817 & 0.0703 & 0.1206 & 1.0000 & & & & & & \\
\hline & .000 & .000 & .769 & .165 & .073 & .382 & .000 & .006 & .000 & & & & & & & \\
\hline \multirow[t]{2}{*}{ CAR } & -0.1754 & -0.1959 & -0.0142 & 0.0602 & 0.0432 & 0.0181 & 0.0776 & 0.0627 & -0.1009 & -0.2087 & 1.0000 & & & & & \\
\hline & .000 & .000 & 0.578 & .021 & .091 & .478 & .002 & .014 & .000 & .000 & & & & & & \\
\hline \multirow[t]{2}{*}{ COF } & -0.1005 & -0.1705 & 0.0509 & 0.1164 & 0.1378 & 0.0838 & 0.0808 & 0.0378 & -0.1226 & -0.1609 & 0.0874 & 1.0000 & & & & \\
\hline & .000 & .000 & .046 & .000 & .000 & .001 & .002 & .138 & .000 & .000 & .001 & & & & & \\
\hline \multirow[t]{2}{*}{ FRX } & 0.2384 & 0.2975 & -0.1249 & -0.2258 & -0.1996 & -0.0596 & -0.1352 & -0.1644 & 0.1743 & 0.2642 & -0.4957 & -0.4951 & 1.0000 & & & \\
\hline & .000 & .000 & .000 & .000 & .000 & .020 & .000 & .000 & .000 & .000 & .000 & .000 & & & & \\
\hline \multirow[t]{2}{*}{ GDP } & 0.2302 & 0.3054 & -0.0474 & -0.1759 & -0.1339 & -0.0339 & -0.1303 & -0.0693 & 0.2186 & 0.3404 & -0.6809 & -0.4536 & 0.8051 & 1.0000 & & \\
\hline & .000 & .000 & .063 & .000 & .000 & .184 & .000 & .007 & .000 & .000 & .000 & .000 & .000 & & & \\
\hline \multirow[t]{2}{*}{ INF } & -0.1872 & -0.1767 & 0.1216 & 0.2736 & 0.1157 & 0.0416 & 0.0931 & 0.1520 & -0.0889 & -0.1430 & 0.0921 & 0.3449 & -0.6095 & -0.4581 & 1.0000 & \\
\hline & .000 & .000 & .000 & .000 & .000 & .103 & .000 & .000 & .001 & .000 & .000 & .000 & .000 & .000 & & \\
\hline \multirow[t]{2}{*}{ LBM } & 0.1831 & 0.2621 & -0.0188 & -0.1394 & -0.1009 & -0.0197 & -0.1114 & -0.0078 & 0.2304 & 0.3354 & -0.5375 & -0.4308 & 0.6155 & 0.9172 & -0.3282 & 1.0000 \\
\hline & .000 & .000 & .461 & .000 & .000 & .441 & .000 & .761 & .000 & .000 & .000 & .000 & .000 & .000 & .000 & \\
\hline
\end{tabular}

Source: Authors, Included observations: 1,564

low-competition firms, respectively. As a result, the use of the ARDL estimation technique was no longer feasible and the GMM technique was adopted in order to estimate the three models. To obtain the GMM estimates, the moment condition was written as the orthogonality condition between the expression including the parameters to be estimated and the set of the instrumental variables that included the lagged explanatory variables. This corrects endogeneity by transforming instruments so as to make them uncorrelated with the error term and improve efficiency.

\section{REGRESSION RESULTS}

The detailed results obtained from the GMM estimation were reported in the three columns of 
Table 4 The unit root test results

\begin{tabular}{|c|c|c|c|c|c|c|c|c|c|c|}
\hline \multirow{2}{*}{ Variable } & & \multicolumn{2}{|c|}{ LLC } & \multicolumn{2}{|c|}{ IPS } & \multicolumn{2}{|c|}{ ADF } & \multicolumn{2}{|c|}{ PP } & \multirow{2}{*}{$\begin{array}{c}\text { Order of } \\
\text { Integration }\end{array}$} \\
\hline & & Stat. & Prob. & Stat. & Prob. & Stat. & Prob. & Stat. & Prob. & \\
\hline FMC & Level & -6.142 & .000 & -6.469 & .000 & 256.214 & .000 & 427.771 & .000 & $\mathrm{I}(0)$ \\
\hline $\ln (A G E)$ & Level & -42.02 & .000 & -365.8 & .000 & 15215.0 & .000 & 14699.0 & .000 & $\mathrm{I}(0)$ \\
\hline AST & Level & -2.385 & .009 & -3.294 & .001 & 195.557 & .001 & 214.247 & .000 & $\mathrm{I}(0)$ \\
\hline \multirow[t]{2}{*}{ CAR } & Level- & 3.623 & .999 & 2.368 & .991 & 61.872 & 1.00 & 72.327 & 1.00 & $\mathrm{I}(1)$ \\
\hline & $1^{\text {st }}$ Diff. & -16.94 & .000 & -11.91 & .000 & 376.246 & .000 & 878.979 & .000 & \\
\hline $\mathrm{COF}$ & Level & -10.47 & .000 & -4.771 & .000 & 184.453 & .004 & 733.524 & .000 & $\mathrm{I}(0)$ \\
\hline $\ln (\mathrm{FRX})$ & Level & -27.45 & .000 & -18.97 & .000 & 601.522 & .000 & 2107.67 & .000 & $\mathrm{I}(0)$ \\
\hline GRW & Level & -12.52 & .000 & -11.75 & .000 & 390.981 & .000 & 636.227 & .000 & $\mathrm{I}(0)$ \\
\hline INF & Level & -6.660 & .000 & -8.840 & .000 & 291.945 & .000 & 214.040 & .000 & $\mathrm{I}(0)$ \\
\hline \multirow[t]{2}{*}{$\ln (\mathrm{LBM})$} & Level & 0.348 & 1.00 & 12.246 & 1.00 & 9.544 & 1.00 & 4.493 & 1.00 & $\mathrm{I}(1)$ \\
\hline & $1^{\text {st }}$ Diff. & -26.57 & .000 & -28.69 & .000 & 926.75 & .000 & 1510.75 & .000 & \\
\hline LEV & Level & -5.618 & .000 & -4.380 & .000 & 221.347 & .000 & 424.022 & .000 & $\mathrm{I}(0)$ \\
\hline LIQ & Level & -16.74 & .000 & -8.508 & .000 & 507.592 & .000 & 482.396 & .000 & $\mathrm{I}(0)$ \\
\hline \multirow[t]{2}{*}{$\ln (\mathrm{NOE})$} & Level & -0.088 & .465 & 1.863 & .969 & 136.140 & .481 & 107.065 & .968 & $\mathrm{I}(1)$ \\
\hline & $1^{\text {st }}$ Diff. & -11.02 & .000 & -11.66 & .000 & 404.901 & .000 & 726.052 & .000 & \\
\hline PRT & Level & -3.833 & .000 & -4.842 & .000 & 229.474 & .000 & 322.457 & .000 & $\mathrm{I}(0)$ \\
\hline \multirow[t]{2}{*}{$\ln (\mathrm{RSK})$} & Level & 8.974 & 1.00 & 7.104 & 1.00 & 128.995 & .652 & 160.346 & .076 & $\mathrm{I}(1)$ \\
\hline & $1^{\text {st }}$ Diff. & -9.371 & .000 & -14.94 & .000 & 527.955 & .000 & 1513.48 & .000 & \\
\hline $\ln (\mathrm{SZE})$ & Level & -11.61 & .003 & -3.336 & .001 & 224.351 & .004 & 283.438 & .002 & $\mathrm{I}(0)$ \\
\hline
\end{tabular}

Source: Authors

Table 5. The first shows the results for all the firms in the sample, the second reports the results for the $\mathrm{HC}$ firms, whereas the third was accounts for the results for the LC firms. A quick glance at the results in the first model reveals the fact that the two-period lagged competitiveness of the firms has a significant positive effect on the current year competitiveness of the firms. It also shows that a total of the seven firmspecific factors and the five environmental factors have a significant effect on the competitiveness of the firms during the periods. While the effect of the capital expenditure ratio of the government, the foreign exchange rates and the inflation rates on the competitiveness of the firms is positive, the effect of the interest rates and developments in the labor market is negative. These results, however, contrast the findings of F. A. Atanda et al (2015) with the exception of the foreign-exchange rates. The exclusion of financial companies and the longer periods covered by this study might have accounted for the differences, since the same estimation technique was used.

In addition, the firms' age, productive assets, profitability and business risk have a significant positive effect on the competitiveness of the firms, whereas sales growth, the employee capacity and the size of the firm have a significant negative effect. The significant results for profitability, risk and growth are supportive of the findings of E. Laitinen (2008), but contrast the findings of F. A. Atanda (2014), in addition to the firms' age, size, employee capacity and productive assets. The contrast might be due to the differences in the used estimation techniques. In the 
same vein that the differences between the companies and the time periods covered by the previous studies accounted for the differences in the results, categorizing the Nigerian non-financial quoted firms into high- and low-competition firms was expected to bring about different results. The data shown in
Table 5 provide the evidence of the varying impact of the factors that influenced the competitiveness of the HC and LC firms in the non-financial sector of the Nigerian economy.

The data for the HC firms (Column 5) and the LC firms (Column 6) reveal the fact that the one-year

Table 5 The GMM regression results

\begin{tabular}{|c|c|c|c|c|c|}
\hline & Variable & A priori Sign & $\begin{array}{c}\text { Model } 1 \\
\text { (All Firms) }\end{array}$ & $\begin{array}{c}\text { Model } 2 \\
\text { (HC Firms) }\end{array}$ & $\begin{array}{l}\text { Model } 3 \\
\text { (LC Firms) }\end{array}$ \\
\hline \multirow{2}{*}{$\begin{array}{l}\text { Lagged dependent } \\
\text { variable }\end{array}$} & FMC(-1) & + & $\begin{array}{c}0.1798 * * \\
{[13.507]}\end{array}$ & $\begin{array}{c}0.3554 * * \\
{[5.809]}\end{array}$ & $\begin{array}{c}0.0624^{*} \\
{[2.357]}\end{array}$ \\
\hline & $\mathrm{FMC}(-2)$ & + & $\begin{array}{c}0.0581 * * \\
{[5.234]}\end{array}$ & - & - \\
\hline \multirow{9}{*}{ Firm-specific factors } & $\ln (\mathrm{AGE})$ & + & $\begin{array}{c}0.2028 * * \\
{[8.137]}\end{array}$ & $\begin{array}{c}14.0510^{*} \\
{[1.763]}\end{array}$ & $\begin{array}{l}-5.2960 \\
{[-1.034]}\end{array}$ \\
\hline & AST & + & $\begin{array}{c}.10 .3315 * * \\
{[7.890]}\end{array}$ & $\begin{array}{l}15.7021 * \\
{[2.369]}\end{array}$ & $\begin{array}{c}6.7253 \\
{[0.808]}\end{array}$ \\
\hline & GRW & + & $\begin{array}{c}-1.6882 * * \\
{[-3.427]}\end{array}$ & $\begin{array}{l}-2.5068 \\
{[-1.490]}\end{array}$ & $\begin{array}{l}-3.8750 * \\
{[-2.188]}\end{array}$ \\
\hline & LEV & - & $\begin{array}{l}-0.0356 \\
{[-0.028]}\end{array}$ & $\begin{array}{l}-4.0598 \\
{[-1.479]}\end{array}$ & $\begin{array}{c}0.1583 \\
{[0.057]}\end{array}$ \\
\hline & LIQ & + & $\begin{array}{c}0.1792 \\
{[0.842]}\end{array}$ & $\begin{array}{l}0.9541 \\
{[1.255]}\end{array}$ & $\begin{array}{l}-2.0617 \\
{[-1.278]}\end{array}$ \\
\hline & $\ln (\mathrm{NOE})$ & + & $\begin{array}{c}-3.8425 * * \\
{[-5.600]}\end{array}$ & $\begin{array}{l}-3.6212 \\
{[-1.113]}\end{array}$ & $\begin{array}{c}-4.7482 * * \\
{[-5.465]}\end{array}$ \\
\hline & PRT & + & $\begin{array}{l}0.3689 * * \\
{[36.220]}\end{array}$ & $\begin{array}{c}0.2593 * * \\
{[3.333]}\end{array}$ & $\begin{array}{c}0.4827^{* *} \\
{[8.510]}\end{array}$ \\
\hline & RSK & + & $\begin{array}{c}0.5226 * * \\
{[8.163]}\end{array}$ & $\begin{array}{l}1.9333 \\
{[1.013]}\end{array}$ & $\begin{array}{c}0.4812 * * \\
{[2.877]}\end{array}$ \\
\hline & $\ln (\mathrm{SZE})$ & + & $\begin{array}{c}-2.1864 * * \\
{[-6.841]}\end{array}$ & $\begin{array}{c}-2.5926 \\
{[-1.1059]} \\
\end{array}$ & $\begin{array}{l}2.1920^{*} \\
{[2.299]} \\
\end{array}$ \\
\hline \multirow{5}{*}{$\begin{array}{l}\text { Macroeconomic } \\
\text { factors }\end{array}$} & CAR & + & $\begin{array}{c}1.8836^{*} \\
{[2.171]}\end{array}$ & $\begin{array}{c}12.0364^{*} \\
{[2.491]}\end{array}$ & $\begin{array}{c}-1.0873 \\
{[-0.260]}\end{array}$ \\
\hline & COF & - & $\begin{array}{c}-0.0750 * \\
{[-2.112]}\end{array}$ & $\begin{array}{l}-0.2180 * \\
{[-2.499]}\end{array}$ & $\begin{array}{c}0.1521 \\
{[1.665]}\end{array}$ \\
\hline & $\ln (\mathrm{FRX})$ & - & $\begin{array}{c}1.8922 * * \\
{[6.335]}\end{array}$ & $\begin{array}{l}2.4291 \\
{[0.831]}\end{array}$ & $\begin{array}{l}-0.4864 \\
{[-0.858]}\end{array}$ \\
\hline & INF & $-1+$ & $\begin{array}{c}0.0772 * * \\
{[9.309]}\end{array}$ & $\begin{array}{l}0.0661 \\
{[1.098]}\end{array}$ & $\begin{array}{c}0.1004 * * \\
{[8.633]}\end{array}$ \\
\hline & $\ln (\mathrm{LBM})$ & + & $\begin{array}{c}-2.7112 * * \\
{[-2.943]} \\
\end{array}$ & $\begin{array}{l}-8.8972 \\
{[-0.807]}\end{array}$ & $\begin{array}{l}0.4803 \\
{[0.243]}\end{array}$ \\
\hline J-statistic & & & 42.3659 & 15.4596 & 14.5102 \\
\hline P-value (J-stat.) & & & 0.8274 & 0.6930 & 0.7532 \\
\hline Instrument Rank & & & 56 & 27 & 27 \\
\hline No. of observation & & & 1,194 & 599 & 595 \\
\hline Cross-section & & & 68 & 34 & 34 \\
\hline
\end{tabular}

Note: The figures in [] are t-statistics. * and ** are the $5 \%$ and $1 \%$ significance levels, respectively

Source: Authors 
lagged competitiveness of the firms positively and significantly contributes to the current year competitiveness of the firms. These show that there is a habit formation in the competitiveness of the firms during the period. However, a stronger habit was detected for the HC firms than for the LC firms, and some factors must have been responsible for that. The firm-specific factors such as the firm's age, productive assets and profitability, as well as the capital expenditure ratio of the government had a significant positive effect on the level of the competitiveness of the HC firms, whereas the prevailing interest rates had a significant negative effect. The results imply the fact that the older firms were more competitive in value creation than the younger firms, whereas in the case of the LC firms, the younger firms were more competitive than the older firms, although the result was not significant. A unit increase in age led to an increase of about 14 percent growth in the competitiveness of the firms, whereas an increase of one percent in profitability caused the competitiveness of the firms to significantly increase by 0.26 percent. Also, the more productive the assets of the HC firms, the greater the competitiveness of the firms. A $1 \%$ increase in the productive assets led to an increase of about 15 percent in the level of the competitiveness of the HC firms, which was an indication of the level of the productivity of the firms' assets. This result fails to provide support to the findings of M. A. Afridi and M. E. Javaid (2015), who established a significant negative effect of productive assets on the competitiveness of the firms operating in the textile industry in Pakistan. However, an increase of one unit in interest rates led to a significant 0.22 percent reduction of in the competitiveness of the firms.

A significant positive effect of the firm's profitability and risk and the size of the firm on the level of the competitiveness of the LC firms was found. These results confirm the findings of E. Laitinen (2008) and R. Asogwa (2009). So, the higher the risk, the higher the level of the competitiveness of the LC firms, ceteris paribus. The HC firms that had a lesser business risk performed better in creating economic value compared to the LC firms. This shows that the LC firms were more aggressive in risk-taking than the $\mathrm{HC}$ firms, and that the business activities engaged in by the LC firms were characterized by a higher level of variability in returns than that of the $\mathrm{HC}$ firms. While the size of the firm contributed significantly and positively to the level of the competitiveness achieved by the LC firms, its effect on that of the HC firms was insignificant, but positive. This means that the asset base was not an important factor for the HC firms in their achieving a high level of competitiveness as it was for the LC firms.

Despite the expected positive impact of the employee capacity and sales growth, there were the negative effects of these factors on the competitiveness of the firms significant at less than 1 and 5 percent, respectively, for the LC firms. While the impact of the employee capacity was significant at less than 1 percent for the LC firms, the impact was, however, not significant for the HC firms, even at a 10 percent level. The negative effect of the employee capacity was an indication of the fact that the increased labor force was not justified, or that the relevant professionals that could have brought about an increased level of competitiveness had not been engaged. It might also be indicative of the fact that the LC firms engaged themselves in more labor-intensive economic activities than the HC firms during the period.

Again, the negative effect of sales growth, which contrasted the a priori expectation, was an indication of the degree of the aggressiveness of the LC firms in growing sales revenue with a negative impact on their competitiveness. Most firms must have engaged themselves in the economic activities that had destroyed, rather than created, positive economic value, or that the level of the economic activities which the firms had engaged themselves in had not led to high economic value, which had made them be low-competition firms. The higher mean value of sales growth for the LC firms than the HC firms had really accounted for a higher magnitude and a significant impact of sales growth on the level of the competitiveness achieved by the LC firms in comparison with that of the HC firms. Increased sales growth was expected to lead to a high level of competitiveness. However, sales growth was found to have a significant negative effect on the competitiveness of the firms, which was indicative of 
the fact that the LC firms were likely experiencing the problem of overtrading, i.e. using too many assets to trade. A cursory look into the composition of the total assets of the firms reveals a high level of the current assets such as inventories and accounts receivables. As sales growth was increasing, the level of competitiveness was decreasing at a very significantly high rate.

At the macro level, the level of the competitiveness achieved by the LC firms and the HC firms was determined as significant, not only by the capital expenditure ratio of the government and the prevailing interest rates, but also by inflation. Of course, the magnitudes and directions of the impact of these factors varied. Inflation can have a dual effect on the performance of a firm because it can cause a disincentive to investments as a result of high operation costs and can lead to increased performance, since inflation is often referred to as changes in the price level. However, the results show that the factor has a positive impact on the competitiveness of the $\mathrm{HC}$ firms and the LC firms, but with a greater significant effect on that of the LC firms. Surprisingly, the interest rates have a significant negative impact on the competitiveness of the $\mathrm{HC}$ firms, but a significant positive effect on that of the LC firms. A $1 \%$ increase in the interest rates led to a significant reduction of about 0.22 percent in the competitiveness of the HC firms, but an increase of about 0.15 percent in the competitiveness of the LC firms. This shows that the interest rates played dual roles in competitiveness and that the LC firms had better ways to absorb the high cost of financing than the HC firms, so that they achieved a higher level of competitiveness.

The other environmental factor that distinguished the HC firms from the LC firms was the capital expenditure ratio of the government. A significant and highly positive impact of the factor on the competitiveness of the HC firms was found. However, the factor played a detrimental role when speaking about the competitiveness of the LC firms; it was not significant, though. This might be the consequence of the types of businesses or the economic activities engaged in by the firms, which were not significantly affected by government policies. Although the exchange rates and developments in the labor market had a significant effect for all the firms, the results indicated an insignificant effect of the factors on the level of the competitiveness of the HC firms and the LC firms separately.

\section{CONCLUSION}

In this study, panel data were used to investigate the influence of firm-specific and environmental factors on the competitiveness of non-financial quoted firms in Nigeria. The competitiveness of the firms, which was computed as a proportion of economic value added to sales revenue, was expressed as the function of its lagged value, a total of nine firm-specific factors and five environmental factors. Descriptive, inferential and econometric tools were used to analyze the study data. The descriptive results showed the diverse features of the HC firms and the LC firms with regard to their levels of competitiveness and firm-specific characteristics.

The results obtained from the econometric analysis indicated the fact that the differences in the basic characteristics of the firms explained the differences in the competitiveness of the firms. The most important factors that can be used to explain the high level of competitiveness included the firms' age, productive assets, profitability, the capital expenditure ratio of the government and the cost of financing (interest rates). While the firms' age, assets tangibility and profitability, and the capital expenditure ratio of the government positively contributed to the achievement of a high level of competitiveness, the cost of financing impedes their potentials. In contrast, while profitability, business risk, the size of the firm and the inflation rates positively contribute to the level of the competitiveness achieved by the LC firms, sales growth and the employee capacity reduce their potentials. The results led to the rejection of the null hypothesis that there is no significant influence of firm-specific and environmental factors on the level of the competitiveness achieved by the $\mathrm{HC}$ and the LC non-financial listed firms in Nigeria. Therefore, a conclusion is drawn that firm-specific 
and environmental factors have both beneficial and detrimental effects on the abilities of the firms to be competitive.

The results portend many policy implications for firms and the government in Nigeria. Firstly, managers, regulators and policy makers will better understand the interactions of firms' characteristics and macroeconomic factors regarding the level of the competitiveness achieved by the non-financial listed firms in Nigeria. The interactions indicated that the managers of LC firms need to be more aggressive in searching for the opportunities that are high in value addition and profitability, since a high discrepancy was found between the average competitiveness and the profitability levels of the firms compared to their HC counterparts.

Secondly, the results showed that the HC firms had failed to leverage on the resources at their disposal (the assets and the employees) in order to achieve high competitiveness, which did not support the position of the resources-based view theory that the internal environment (resources, strategies, structures, etc.) of firms assist them to achieve high competitiveness. However, the significant results of the capacities of the HC firms (expressed in terms of the reputation built over a number of the years of their incorporation, efficiency in the use of the resource-profitability and asset structures) regarding the competitiveness of the firms and the results for the LC firms regarding profitability and business risk indicated support for the resource-based view theory. Again, the results regarding the sales growth potentials of the LC firms were not supportive of the position of the theory that a firm's capabilities in transforming its resources help it achieve economic gains. The significant negative effect of sales growth for the LC firms and its negative, but insignificant, effect for the HC firms practically showed that all the firms engaged in some economic activities had not enhanced their competitiveness levels during the period. Again, the low level of profitability for both the HC firms and the LC firms was an indication of the need for efficient resource utilization and cost reduction or control, or both. The $\mathrm{HC}$ firms need to be more aggressive in sales either through sales promotion or direct marketing, given the fact that they have potentials for creating higher value from economic activities than the LC firms do.

Thirdly, the descriptive results showed that the LC firms had a marginal higher mean asset tangibility with a smaller standard deviation than the HC firms. However, the factor did not significantly affect the competitiveness of the LC firms, which was an indication of the low level of the fixed tangible assets that may lead to a high level of competitiveness. The investment policies of the selected firms should therefore be looked into. The results of the significant positive influence of the size of the firm on the competitiveness of the LC firms also supported the need for more investment opportunities. Also, the significant negative impact of sales growth on the competitiveness of the firms pointed to the fact that the LC firms should examine their trade and credit policies so as to control slow-moving or outdated stocks and overstocking, and prevent the eventual cash flow problem and liquidation. Moreover, the negative effect of the employee capacity on the competitiveness of the LC firms called for a review of the policies on the type, number and quality of the employees engaged by the firms. An emphasis should be placed on the key professionals that can significantly contribute to the value creating potentials of the firms. The value appropriation and retention, as well as remuneration, policies of the firms should also be looked into.

Fourthly, a part of the environmental influences that a firm should address in the Nigerian economic system is the rising and unstable pricing system (inflation), foreign-exchange fluctuations, social and economic infrastructures, which are always inadequate, a high cost of financing as a result of sky-rocketing interest rates, and developments in the labor market that have led to an increased workers' remuneration since 2001. Although the overall results show that the capital expenditure of the government intended to address inadequate infrastructures, foreign-exchange rates and inflation rates has positively contributed to the competitiveness of the firms, the results for the $\mathrm{HC}$ firms indicate the fact that the firms failed to deal with the fluctuations in foreign-exchange rates, the cost of financing, inflation rates and developments in 
the labor market during the period covered by this study. Therefore, all the firms need to examine their strategies and resources deployed for dealing with instability in the economic environment. The fact that the capital expenditure of the government had a significant positive impact on the competitiveness achieved by the HC firms was indicative of the fact that physical infrastructures were still a 'sin-quanon' for the performance of the private sector. The government should, therefore, continue with its efforts in increasing expenditures on social and economic infrastructures (education, power and roads), as has been reflected in annual budgets in recent times, and their successful implementation, so that an improvement can be made in economic activities and a higher level of the competitiveness of firms in Nigeria. It is also important that the economic policies issued by the government and relating to the financial sector should encourage investments in the critical industrial sectors. The interest rate should be pegged at a single-digit rate, since it was found to be detrimental to the high competitiveness of firms.

There are some limitations inherent in this study, one part of which imply that, out of the various elements pointed to by resource-based view theory and the assets-processes-performance framework (resources, strategies (operations and marketing), technology, innovations, capabilities, structures, relationships management, brands and competencies), only resources and capabilities were included in the model of the competitiveness of firms. For example, as a part of a firm's strategies, the employee mix, rather than the number of employees, may be included. The employee mix points to the quality of the staff rather than their quantity, and a mix of more experienced and professional staff rather than a mix of unskilled or semi-skilled employees will provide the firm with more capabilities than if the firm were smaller. According to resource-based theory, a firm with a relatively small amount of resources, but with a high ambition to achieve competitiveness may in fact leverage on the resources to have greater outputs from smaller inputs and will be able to increase its resources if using the resources effectively and efficiently. This also shows that the size of resources does not matter. This study did not consider the industry, the firms' ambitions, the technology level, brands and relationships management in the model, either. However, researchers' major consideration will be how to measure variables such as brands, innovation, the technology level and the ambition of a firm. Again, a firm's openness to trade, which can be measured by the ratio of the trade credits used by the firm during a period of time over the trade credits given to its own customers was not included. A firm's use of more trade credits than it gives is an internal source of financing at a low cost or at no cost at all, which may consequently increase the firm's capacity to be more competitive. Besides, other measures, apart from EVA, such as market shares, productivity and customer satisfaction, can be used to measure the competitiveness of a firm. In addition, there are many other macroeconomic variables, such as the gross domestic product, money supply and developments in the capital markets that are not included in this study due to the multicollinearity problem. Further studies should endeavor to include these variables in their models.

\section{REFERENCES}

Abernethy, M., \& Lillis, A. (1995). The impact of manufacturing flexibility on management control system design. Accounting, Organization and Society, 20(4), 241-258. doi.org/10.1016/0361-3682(94)e0014-L

Adenikinju, A. (2005). Productivity performance in developing countries: Country case studies Nigeria. PAPER - Drivers of Firm Competitiveness- corrected.docx, UNIDO.

Afridi, M. A., \& Javaid, M. E. (2015). Determinants of competitiveness in textile industry of Pakistan. International Letters of Social and Humanistic Sciences, 61, 105-115. doi. org/10.18052/www.scipress.com/ilshs.61.105

Akalu, M. (2002). Measuring and ranking value drivers. A Discussion Paper, The Timbergen Institute for Economic Research of the Erasmus University, Amsterdam.

Akben-Selcuk, E. (2016). Factors affecting firm competitiveness: Evidence from an emerging market. International Journal of Financial Studies, 4(9), 1-10. doi:10.3390/ijfs4020009 
Ambastha, A., \& Momaya, K. (2006). Competitiveness of firms: Review of theory, frameworks and models. Singapore Management Review, 26(1), 45-61.

Asogwa, R. (2009July). Measuring the determinants of value creation for publicly listed banks in Nigeria: A random effects probit (REP) model analysis. Paper presented at the 14th Annual Conference on Econometric Modeling for Africa, held at Cape Town, South Africa.

Atanda, F. A.(2014). Valuecreationandappropriation in the Nigerian non-financial quoted companies. An unpublished doctorate thesis submitted to the Department of Management and Accounting, Obafemi Awolowo University, Nigeria.

Atanda, F. A., \& Asaolu, T. (2015). Developments in value creation and appropriation of Nigerian non-financial quoted companies. British Journal of Economics, Management and Trade, 9(1), 1-13. doi:10.9734/bjemt/2015/18640

Atanda, F. A., Asaolu, T., \& Oyerinde, A. (2015). Macroeconomic variables and value creation in the Nigerian quoted companies. International Journal of Economics and Finance, 7(6), 252-262. doi:10.5539/ijef.v7n6p252

Barney, J. (1991). Firm resources and sustained competitive advantage. Journal of Management, 17(1), 99-120.

Booth, L. (1998 October). What drives shareholder value? Paper Presented at the Federated Press' Creating Shareholder Value Conference, Toronto, Canada.

Daily, C., \& Dollinger, M. (1993). Alternative methodologies for identifying family versus non-family managed businesses. Journal of Small Business Management, 31(2), 79-90.

Egbunike, C., \& Okerekeoti, C. (2018). Macroeconomic factors, firm characteristics and financial performance: A study of selected manufacturing firms in Nigeria. Asian Journal of Accounting Research, 3(2), 142-168. doi:10.1108/ajar-09-20180029

Hamel, G., \& Prahalad, C. (1993). Strategy as stretch and leverage. Harvard Business Review, 71(2), 75-84. doi:10.1016/ S1471-7727(00)00002-6

Jorgensen, D. (1967). The theory of investment behaviour. Retrieved February 2, 2017, from www.economics.harvard. edu/faculty/jorgenson/complete_puhlications

Korankye, T., \& Adarquah, R. (2013). Empirical analysis of working capital management and its impact on the profitability of listed manufacturing firms in Ghana. Research Journal of Finance and Accounting, 4(1), 124-131.
Lall, S. (2001). Competitiveness, technology and skills. Cheltenham, UK: Edward Elgar Publishing.

Laitinen, E. (2008). Value drivers in finnish family-owned firms: Profitability, growth and risk. International Journal of Accounting and Finance, 1(1), 1-41.

Liargovas, P., \& Skandalis, K. (2008). Factors affecting competitiveness: The case of Greek industry. Retrieved June 16, 2016, from at www.lse.ac.uk/europeaninstitute/research.../ SKANDALIS_KONSTANTINOS.pdf

Lieberman, M., \& Balasubramanian, N. (2007June). Measuring value creation and its distribution among stakeholders of the firm. Paper Presented at the Academy of Management Annual Meeting, 2005 and the Atlanta Competitive Advantage Conference.

McConaughy, D., Matthews, C., \& Fialko, A. (2001). Founding family-controlled firms: Пerformance risk and value. Journal of Small Business Management, 39(1), 31-48. doi:10.1111/0447-2778.00004

Mouldi, D., Abdelaziz, H., \& Ilehmi, H. (2011). Single versus multiple bank relationships and firm performance: An econometric model for some Tunisian firms. International Research Journal of Finance and Economics, 63, 46-54.

Navaretti, B., Bugamelli, M., Schivadi, F., Altomonte, C., Horgos, D., \& Maggiani, D. (2011). The global operations of European firms. The Second EFIGE Policy Report. Bruesel Blueprint Series 12.

Odior, E. (2013). Macroeconomic variables and the productivity of the manufacturing sector in Nigeria: A static analysis approach. Journal of Emerging Issues in Economics, Finance and Banking, 1(5), 362-380.

Onakoya, A. (2018). Macroeconomic dynamics and the manufacturing output in Nigeria. Mediterranean Journal of Social Sciences, 9(2), 43-54. doi.org/10.2478/mjss-2018-0024

Onyemenam, C. (2004June). Firm Level Competitiveness in Nigeria. Paper presented at the ODI-NESG Seminar on Maximizing pro-poor growth: Regenerating the socioeconomic database in Nigeria held at the City University, Northampton Square, London, UK.

Porter, M. (1999). Microeconomics competitiveness: Findings from the 1999 executive survey. The Global Competitiveness Report. Geneva, Switzerland: World Economic Forum.

Porter, L., Lawler, E., \& Hackman, J. (1975). Behaviour in Organizations. New York, NY: McGraw-Hill. 
Prahalad, C., \& Hamel, G. (1990). The core competence of the Corporation. Harvard Business Review, 68(3), 79-91.

Samuel, J., Pulimi, M., Paul, M. L., Maurya, A., Natarajan Chandrasekaran, N., \& Mukherjee, A. (2013). Batch and continuous flow studies of adsorptive removal of $\mathrm{Cr}(\mathrm{VI})$ by adapted bacterial consortia immobilized in alginate beads. Bioresource Technology, 128, 423-430. doi.org/10.1016/j. biortech.2012.10.116
Shee, H. (2002). Competitiveness through Technological Excellence: A Case of Indian Software Industry. Doctoral Research, Department of Management Studies, IIT Delhi, India.

Smith, S. (1995). World class competitiveness. Managing Service Quality, 5(5), 36-42.

$$
\begin{array}{r}
\text { Received on } 17^{\text {th }} \text { March } 2020, \\
\text { after revision, } \\
\text { accepted for publication on } 17^{\text {th }} \text { August } 2020 . \\
\text { Published online on } 19^{\text {th }} \text { August } 2020 .
\end{array}
$$

Fatai Abiodun Atanda, $\mathrm{PhD}$ in Accounting, is a fellow of the Institute of Chartered Accountants of Nigeria. He is a lecturer at the Department of Accounting, University of Ibadan, Nigeria. His research interests are in the area of Sustainability Accounting, Corporate Financial Management and Small Business Development and Financing.

Olubunmi Florence Osemene, PhD in Accounting and Finance, is a fellow of the Institute of Chartered Accountants of Nigeria. He is an associate professor at the University of Ilorin, Nigeria. His research interests are in the area of Management Accounting and Environmental Accounting. 


\section{APPENDIX}

Table A1 The Box-Jenkins statistics for endogeneity (Correlogram) for all the firms (at the level)

\begin{tabular}{|c|c|c|c|c|c|c|}
\hline \multicolumn{7}{|l|}{ Sample: 19962017} \\
\hline \multicolumn{7}{|c|}{ Included observations: 1534} \\
\hline Autocorrelation & Partial Correlation & & $\mathrm{AC}$ & PAC & Q-Stat & Prob \\
\hline$|* * * *|$ & $\left.\right|^{*} \mid$ & 1 & 0.494 & 0.199 & 809.09 & 0.000 \\
\hline$|* * *|$ & $\left.\right|^{*} \mid$ & 2 & 0.443 & 0.136 & 1068.9 & 0.000 \\
\hline$|* * *|$ & 1 1 & 3 & 0.369 & 0.030 & 1249.3 & 0.000 \\
\hline |** | & | 1 & 4 & 0.318 & 0.024 & 1383.2 & 0.000 \\
\hline$|* *|$ & | | & 5 & 0.303 & 0.059 & 1504.8 & 0.000 \\
\hline$|* *|$ & 1 & 6 & 0.250 & -0.013 & 1587.6 & 0.000 \\
\hline |** | & 1 1 & 7 & 0.214 & -0.002 & 1648.5 & 0.000 \\
\hline * & 11 & 8 & 0.200 & 0.021 & 1701.9 & 0.000 \\
\hline
\end{tabular}

Source: Authors

Table A2 The Box-Jenkins statistics for endogeneity (Correlogram) for the high-competition firms (at the level)

\begin{tabular}{|c|c|c|c|c|c|c|}
\hline \multicolumn{7}{|l|}{ Sample: 19962017} \\
\hline \multicolumn{7}{|c|}{ Included observations: 769} \\
\hline Autocorrelation & Partial Correlation & & $A C$ & PAC & Q-Stat & Prob \\
\hline.$|* * *|$ &.$^{*}$ & 1 & 0.431 & 0.106 & 527.08 & 0.000 \\
\hline.$|* *|$ &. $\mid$ & 2 & 0.345 & 0.008 & 606.44 & 0.000 \\
\hline.$|* *|$ &.$|. \quad|$ & 3 & 0.266 & -0.026 & 653.75 & 0.000 \\
\hline$.\left.\right|^{* *} \mid$ &.$|. \quad|$ & 4 & 0.245 & 0.045 & 693.91 & 0.000 \\
\hline$.^{*} \quad \mid$ &. & 5 & 0.184 & -0.025 & 716.54 & 0.000 \\
\hline$.^{*} \mid$ &. $\mid$ & 6 & 0.166 & 0.025 & 735.06 & 0.000 \\
\hline$.\left.\right|^{*} \quad \mid$ &.$|. \quad|$ & 7 & 0.150 & 0.020 & 750.24 & 0.000 \\
\hline $.1^{*}$ & .1 .1 & 8 & 0.134 & 0.012 & 762.24 & 0.000 \\
\hline
\end{tabular}

Source: Authors

Table A3 The Box-Jenkins statistics for endogeneity (Correlogram) for the low-competition firms (at the level)

\begin{tabular}{|c|c|c|c|c|c|c|}
\hline \multicolumn{7}{|l|}{ Sample: 19962017} \\
\hline \multicolumn{7}{|c|}{ Included observations: 765} \\
\hline Autocorrelation & Partial Correlation & & $A C$ & PAC & Q-Stat & Prob \\
\hline. $\mid * *$ &.$|* *|$ & 1 & 0.344 & 0.344 & 78.473 & 0.000 \\
\hline$.^{*} \quad \mid$ & .. $\quad \mid$ & 2 & 0.174 & 0.063 & 98.594 & 0.000 \\
\hline.$\left.\right|^{*}$ &. $\mid$ & 3 & 0.123 & 0.051 & 108.58 & 0.000 \\
\hline.$|. \quad|$ &.$|. \quad|$ & 4 & 0.034 & -0.035 & 109.34 & 0.000 \\
\hline. $\mid 1$ &. $\mid 1$ & 5 & 0.017 & 0.002 & 109.54 & 0.000 \\
\hline.$|. \quad|$ &.$|\quad|$ & 6 & -0.020 & -0.033 & 109.81 & 0.000 \\
\hline.$|. \quad|$ &.$|. \quad|$ & 7 & -0.014 & 0.003 & 109.94 & 0.000 \\
\hline. $\mid 1$ &.$|\quad|$ & 8 & -0.038 & -0.033 & 110.89 & 0.000 \\
\hline
\end{tabular}

Source: Authors 


\title{
THE DRIVERS OF THE COMPETITIVENESS OF FIRMS IN THE NON-FINANCIAL SECTOR: EVIDENCE FROM NIGERIA
}

\author{
Fatai Abiodun Atanda ${ }^{*_{1}}$ and Florence Olubunmi Osemene ${ }^{2}$ \\ 'Department of Accounting, University of Ibadan, Nigeria \\ ${ }^{2}$ Department of Accounting and Finance, University of Ilorin, Nigeria
}

This study examines the key determinants of the competitiveness of firms in Nigeria. It draws the firmlevel (i.e. firm-specific characteristics) data and macro-data (environmental factors) from the annual reports and accounts of non-financial listed firms and the Statistical Bulletin of the Central Bank of Nigeria, respectively. In addition, it employs descriptive, inferential and econometric tools to analyze the data. The results reveal that the age of a firm, its productive assets, profitability and the capital expenditure ratio of the government enhanced the competitiveness of high-competition firms, on the one hand, while the high cost of finance hindered it, on the other. However, profitability, business risk, the size of a firm and inflation contributed to the competitiveness of low-competition firms, on the one hand, while sales growth and employees' capacity reduced it, on the other. It was concluded that both firm-specific and environmental factors played the beneficial and detrimental roles when the level of the competitiveness achieved by the Nigerian non-financial listed firms is concerned. Thus, the policy implications of these results were discussed.

Keywords: high-competition firm, low-competition firm, value creation, firm-specific factor, environmental factor

JEL Classification: M41, G32

\section{INTRODUCTION}

The effect of globalization and the need to meet the increasing varieties of customer needs require that contemporary businesses should achieve a competitive advantage. In addition, the number of the companies

* Correspondence to: F. A. Atanda, Department of Accounting, University of Ibadan, Nigeria;

e-mail: atanda2001uk@yahoo.co.uk that folded up during and after the 2008 economic crisis and the 2015 economic meltdown signaled to the surviving ones the need to increase their level of competitiveness in their industrial sectors, which then led us to the question, 'How can firms be made competitive?' M. Porter (1999) strives to answer this question by positing that being competitive requires businesses to develop an increasing interest in the key strategic management processes and operations, 
which means that businesses should make the competition-related decisions that may lead to the creation of increased economic value. A business creates value when it generates wealth from economic activities, transforming inputs into outputs. Therefore, value is referred to as the difference between an output value and an input value (Booth, 1998), which can be either positive, when a firm is able to cover the actual and opportunity costs of the purchased inputs or components used to generate sales revenue, or negative, when a firm is unable to cover its input costs.

Although Nigerian quoted firms operate within the same economic conditions, some of them create positive economic value (EVA) and some create negative value (Atanda \& Asaolu, 2015). In addition, some of them create higher economic value from a given level of economic activities or sales revenue than others, while some destroy it. These make some of them high-competition (HC) and low-competition (LC) firms in value creation. The differences in the levels of competitiveness may appear as a result of their differing capacities, capabilities and resources, which also vary from time to time. This is because the ability of a firm to develop and deploy its capabilities and talents far more effectively than its competitors helps it to achieve world-class competitiveness (Smith, 1995). Firms' capabilities, therefore, revolve around internal factors or firm-specific characteristics, such as the organizational structure, productive assets, growth and risk.

According to M. Porter (1999), competitiveness revolves around a combination of a country's conditions and a firm's strategy to seize opportunities provided by those conditions. This means that the economic conditions of a country may bring about many challenges and opportunities at the firm, industry and country levels and shaken confidence in businesses (Ambastha \& Momaya, 2006). It also means that environmental conditions, such as natural resources, infrastructures, government policies (fiscal and monetary) and the level of economic growth, may also have an influence on the competitiveness of a firm. Therefore, in order for a firm to be competitive in value creation, it should succeed in dealing with challenges and limitations posed by the environment, market developments and the economic conditions of a country.

Previous studies established the fact that quoted firms in Nigeria had a potential for value creation (Akalu, 2002; Asogwa, 2009; F. A. Atanda and T. Asaolu, 2015). F. A. Atanda and T. Asaolu (2015) provided the empirical evidence that showed that, in recent times, companies had created an economic value greater than in previous periods, in real terms. However, there is unarguably a lack of ample empirical evidence of the reasons why some of the firms were highly competitive in value creation while others were not, although operating under the same environmental, market and economic conditions. That pointed to the specific business research problem of how the firms could be made highly competitive in creating economic value. This study examines the key factors that have contributed to the level of the competitiveness achieved by non-financial quoted firms in Nigeria. The fact that firm-specific and environmental factors do not have significant effects on the level of the competitiveness achieved by $\mathrm{HC}$ firms and LC firms in Nigeria is hypothesized herein.

The main contributions of this paper are articulated in the following: first, non-financial listed firms operate within the same economy, with a high tendency to experience similar shocks from environmental variables, such as inflation, interest rates, government policies and foreign-exchange rates, with similar consequences for their performances. However, the available data show that the firms differ greatly in terms of the level of competitiveness, efficiency in resource utilization (profitability), employees' capacity and risk appetite (business risk), which made them be categorized into high-competition and lowcompetition firms; second, while acknowledging a few notable studies, namely those by A. Ambastha and K. Momaya (2006), P. Liargovas and K. Skandalis (2008), B. Navaretti, M. Bugamelli, F. Schivadi, C. Altomonte, D. Horgos and D. Maggiani, (2011), M. A. Afridi and M. E. Javaid (2015), E. Akben-Selcuk (2016), A. Onakoya (2018), the issue of unequal meanings, factors (and their impacts), as well as different adopted methodologies, needs further 
examination in terms of measurement and modelling. Competitiveness is a concept not well-understood despite its widespread usage (Onyemenam, 2014) and a complete competitiveness analysis must define how it is measured and identify the most important factors that influence it (Lall, 2001). Thus, unlike in the previous studies, where the absolute figures of sales, earnings and market value were used, this present study follows the Assets-Processes-Performance (APP) framework to measure the competitiveness of a firm as a proportion of EVA to sales revenue, relative to other firms. This is due to the superiority of EVA over accounting metrics (Booth, 1998). In addition, the Generalized Method of Moments (GMM) is employed in order to estimate the linear regression model due to the outcome of the Partial Autocorrelation (PAC) test conducted on the time series properties of the dependent variable (the competitiveness of a firm) by using the Box-Jenkins Q-statistic method; third, this study adds to the existing literature on the competitiveness of firms, namely A. Ambastha and K. Momaya (2006), P. Liagovas and K. Skandalis (2008), Navaretti et al, (2011), M. A. Afridi and M. E. Javaid (2015), E. Akben-Selcuk (2016), by conducting a comprehensive and robust analysis, simultaneously accounting for the firm-specific factors such as the size of a firm, its age (in order to measure the reputation of a firm), employees' capacity, liquidity, leverage, risk, growth, productive assets and profitability, as well as environmental factors, such as inflation, the cost of finance (interest rates) and developments in the labor market. This is consistent with the position of the RBV theory that a firm's internal environment is critical to the strategic actions that will be undertaken so as to achieve a competitive advantage and the argument of L. Porter, E. Lawler and J. Hackman (1975) that only the organizations that are able to deal with the demands of their environment or environmental influences will achieve the best.

The rest of the paper is organized into four sections: Section Two deals with a review of theoretical and empirical studies; Section Three covers the research methods; Section Four provides the results of the data analysis, and Section Five gives the conclusion of the study.

\section{THEORETICAL AND EMPIRICAL REVIEWS}

The theory of the Resource-Based View (RBV) and the Assets-Processes-Performance (APP) framework form the bedrock of this study. The RBV considers a firm as a collection of unique resources and capabilities, which provide the basis for the strategies that are the primary sources of earnings. It posits that a firm with a relatively small amount of resources, but with a high ambition, may leverage their resources so as to achieve a greater output for its smaller inputs and that, with increased effectiveness, the resources that will be available to the firm may be larger (Hamel \& Prahalad, 1993). The theory is grounded in the perspective that a firm's internal environment (in terms of its resources and capabilities) is more critical to the determination of strategic actions to undertake in order to achieve a sustainable competitive advantage in its market and industry. However, this is not to say that the external environment is not important. This is because there are some environmental influences that a firm should deal with and only organizations whose internal features match the demands of their environment best will achieve the best (Porter et al, 1975).

In fact, changes inside and outside a firm put more responsibilities on its managers regarding the manner in which the problem of instability in environmental variables, such as developments in the financial market, inflation and government policies, will be addressed. Instead of accumulating the resources needed to implement the strategies dictated by external environmental conditions, the theory expects that a firm's unique resources and capabilities will provide the basis for a strategy, and the strategy will allow the firm to best exploit its core competencies relative to opportunities in the environment (Hamel \& Prahalad, 1993). In addition, the theory expects a firm to manage its resources and capabilities in its pursuit of aboveaverage returns and implement the strategies that can help achieve goals in an efficient manner. It must be noted that resources themselves confer no value to a firm. It is only when they are put into a productive use that value can be created. Therefore, this means that differences in firms primarily driven by their unique resources and capabilities will contribute to a firm's ability to be highly competitive over time. The 
firms that face similar industrial or market conditions are ordinarily expected to exhibit a certain degree of similarity in performance. Due to differences in internal structures, how resources are combined and capacities to utilize resources in the most competitive ways, a great divergence in firms' performances may be detected. This is because not all the resources that a firm has access to are strategically relevant (Barney, 1991). Some resources may actually prevent a firm from conceiving and implementing valuable strategies, whereas an efficient combination of resources may lead to the competencies and strategies that may reduce inefficiency. The major limitation of the RBV is that it does not guide policy makers how to integrate a strategy with competitiveness.

However, the Assets-Processes-Performance (APP) framework, which integrates resources with performance through processes, provides a better tool for the integration of a strategy with the competitiveness of a firm (Shee, 2002). The framework provides managers with the means of the categorization of the sources of competitiveness, their relevance and performance. Under the 'Assets', the sources of the competitiveness of a firm include brands, reputation, human resources and technology. However, the sources include a strategy, innovations, relationship management, manufacturing and marketing under the 'Processes', whereas under the 'Performance', they include customer satisfaction, value creation, a market share and productivity (Ambastha \& Momaya, 2006). This means that competitiveness requires a combination of the resources and the process used to transform the resources so as to achieve economic gains. Some firms are more competitive than others, due to their varied internal factors, such as strategies, structures, competencies, resources and capacities, in order to innovate in the areas such as financing, resources allocation and production (Prahalad \& Hamel, 1990). At the firm level, therefore, to be competitive means to create higher economic value from product and service designing, production and marketing.

The literature review showed that finance, assets, revenue growth opportunities and several characteristics of a firm influenced the competitiveness of a firm. In fact, the value of a firm changes over time as a result of changes in the size of the company, i.e. when the company changes the quantity of the resources used without changing the efficiency of the resources used (Lieberman \& Balasubramanian, 2007). D. Mouldi, H. Abdelaziz and H. Ilehmi (2011) found that the size positively and significantly affected the value of a firm measured by return on assets and return on equity. A significant positive effect of the size of a firm measured by the natural logarithm of the firm's total assets on value creation measured by economic value added (EVA) and Free Cash Flows (FCF) was also found by F. A. Atanda (2014). In addition, while exploring the relationship between the characteristics of a firm and the financial performance of the quoted manufacturing firms operating in the consumer goods sector of the Nigerian economy, C. Egbunike and C. Okerekeoti (2018) found a significant effect of the characteristics of a firm, such as the size, leverage and liquidity, on return on investment.

Growth is an important goal for the largest number of corporations because, according to C. Daily and M. Dollinger (1993), it is only through growth that professional managers can find new opportunities. However, F. A. Atanda (2014) found a weak, positive and insignificant effect of sales growth on EVA and a significant positive effect of sales growth on a free cashflow. Differences in age may also account for the reason why some companies are more competitive in creating value than others. D. Mouldi et al, (2011) found that age had a positive and significant effect on a firm's performance, because old firms were able to build their reputation in comparison with young ones. Risk can be defined as the probability that actual returns will deviate from expected returns (McConaughy, Matthews \& Fialko, 2001). This is often measured by using the standard deviation of returns. In addition, risk can be measured as a ratio of external (i.e. debts) to internal (equity) financing or the extent to which a firm's assets are financed by externally sourced funds. This showed that there were two categories of risk:

- business risk, which cannot be diversified, and

- finance risk, which can be diversified. 
The debt capacity was used by J. Jorgensen (1967), where it was found that a higher debt led to a higher capacity to embark on the investments that enhanced value. So, a higher finance risk led to higher investments, which might lead to higher returns, ceteris paribus. While the significant positive effect of finance risk on a firm's performance was found by E. Laitinen (2008) and R. Asogwa (2009), the result obtained by F. A. Atanda (2014) regarding the effect of business risk on EVA was insignificant and weak, although positive. In addition, J. Samuel, M. Pulimi, M. L. Paul, A. Maurya, N. Chandrasekaran and A. Mukherjee (2013) examine the impact of long-term debts on the value of the firms listed on the Ghana Stock Exchange (GSE), and concludes that the variable has a statistically significant impact on the value of a firm.

Moreover, P. Liargovas and K. Skandalis (2008) found a significant positive relationship between the number of employees and the competitiveness of a firm measured by the profitability of Greek companies. B. Navaretti et al, (2011) also found a significant positive relationship between the intensity of the skills of the workforce and the competitiveness of a firm by using a combination of questionnaire survey data and the firm-level financial data on European firms. Asset tangibility shows the structure of the assets employed by a company. The companies engaged in production and services have a different asset structure, which leads to differences in the degree of replication, routine and the task variety (Abernethy \& Lillis, 1995), which, therefore, may result in different value creation potentials. Moreover, a stable environment was regarded as important for a firm's performance and the competitiveness of an economy. In fact, there are pieces of evidence that businesses are best conducted in an environment of stability with the minimum level of uncertainty (A. Adenikinju, 2005). The variables used as proxies in many studies included a gross domestic product, inflation, foreign exchange rates, developments in (labor and financial) markets, interest rates, physical infrastructures and government regulations and policies (Odior, 2013; Atanda, Asaolu \& Oyerinde, 2015; Egbunike \& Okerekeoti, 2018; Onakoya, 2018).
According to X. Z. Zhang and S. S. Mirza (2015), inflation is a very important factor for a country's stable growth and any increase in the inflation rate may bring uncertainty to the economy. E. Odior (2013) employed the cointegrating equation of the Vector Error Correction Model (VECM) so as to examine the impact of the macroeconomic variables such as interest rates on the productivity of manufacturing firms in Nigeria. The author found a negative effect of the cost of borrowing, which was due to the high interest rates on the output growth both in the short run and in the long run. However, using the Johansen cointegration test, A. Onakoya (2018) found no short-term effect of the exchange rates and the gross domestic product on the manufacturing output in Nigeria. In addition, C. Egbunike and C. Okerekeoti (2018) found no significant effect for the interest rate and the exchange rate, but did find a significant effect for the inflation rate and the gross domestic product growth rate on the return on investment of some selected manufacturing firms listed on the Nigerian Stock Exchange. F. A. Atanda et al, (2015) found a significant negative effect of inflation on the value created by the Nigerian quoted firms during the period from 2001-2012. Using the generalized method of the moments estimation technique, the authors also found significant positive effects of exchange rates, interest rates, the gross domestic product growth and developments in the labor market on value creation. It is, however, unknown whether these variables have significant effects on the level of the competitiveness achieved by firms.

The foregoing shows that the financial performance of both financial and non-financial firms in Nigeria, as well as the factors that determined it, has been done research into, paying little or no attention at all on the competitiveness of the firms. Despite the recorded performance, some of the firms folded up as a result of the economic crises experienced in the past, whereas those that had survived made decisions related to competition, which led to the creation of increased economic value. There is, therefore, the need to extend the knowledge by capturing the firmspecific and environmental factors that contribute 
to the competitiveness level achieved by firms. The consideration and a robust analysis of the key factors will lead to the policy issues that can be used to improve the competitiveness of firms amongst the non-financial listed firms in Nigeria.

\section{METHODOLOGY}

The panel data collected from the annual reports and accounts of the 68 non-financial listed firms in Nigeria and the time series data collected from the annual Statistical Bulletin of the Central Bank of Nigeria, the 2017 edition, during the period from 1995-2017 were employed in this study. The sample was divided into the two groups of an equal size: the LC and HC firms. A firm characterized by an average competitiveness (i.e. the proportion of EVA to sales revenue relative to other firms) greater than the overall average for the sample was considered as an HC firm; otherwise, it was categorized as an LC firm. Although correlation analysis helps identify the exogenous variables in the model, it does not provide guidance to the process that generated the dependent variable, i.e. the competitiveness of a firm. Therefore, the time series properties of the competitiveness of firms were explored by using the Box-Jenkins Q-statistic method. The autocorrelation and partial autocorrelation functions were plotted to determine whether the variable followed the autoregressive (AR) or moving average (MA) or both (ARMA) processes and the period(s). The lagged dependent variable was added to the right-hand side of the model, due to the autoregression of the variable at the lag order AR(n). The effect of the firm-specific and environmental factors on the competitiveness of firms is modeled by using the following linear equation:

$$
\begin{aligned}
& \text { FMC }_{i t}=\alpha+\beta_{1} \operatorname{InAGE}_{i t}+\beta_{2} \mathrm{COF}_{i t}+\beta_{3} \operatorname{InFRX}_{i t}+ \\
& \beta_{4} \mathrm{CAR}_{i t}+\beta_{5} \operatorname{InSZE}_{i t}+\beta_{6} \mathrm{LEV}_{1, i t}+\beta_{7} \mathrm{GRW}_{i t}+ \\
& \beta_{8} \mathrm{RSK}_{i t}+\beta_{9} L I \mathrm{Q}_{i t}+\beta_{10} A S T_{i t}+\beta_{11} \operatorname{InNOE}_{i t}+ \\
& \beta_{12} \mathrm{PRT}_{i t}+\beta_{13} I_{i t}+\beta_{14} \mathrm{LBM}_{i t}+ \\
& \beta_{j} \sum_{j=1}^{n} \mathrm{FMC}_{i, t-j}+\mu_{i t}
\end{aligned}
$$

where, FMC is the competitiveness of a firm $i$ at the time $t, A G E$ is the number of the years of being in operations from the date of incorporation for the firm $i$ at the time $t, C O F$ is the cost of financing for the firm $i$ at the time $t, F R X$ is the prevailing foreign exchange rate for the firm $i$ at the time $t, C A R$ is the capital expenditure ratio of the government for the firm $i$ at the time $t$, SZE is the size of the firm $i$ at the time $t, L E V$ is the leverage for the firm $i$ at the time $t$, $G R W$ is the growth in sales for the firm $i$ at the time $t, R S K$ is the risk for the firm $i$ at the time $t, L I Q$ is the liquidity ratio of the firm $i$ at the time $t, A S T$ is the productive asset for the firm $i$ at the time $t, N O E$ is the number of the employees in the firm $i$ at the time $t$, PRT is profitability (i.e. operating efficiency) for the firm $i$ at the time $t$, INF is the inflation rate for the firm $i$ at the time $t$, LBM is the developments in the labor market for the firm $i$ at the time $t$, In is the natural logarithm sign, $\alpha$ is the constant, $\beta_{i}$ is the coefficients to be estimated for the explanatory variables and $\mu$ is the stochastic error term. The variables in the model are measured as shown in Table 1.

The variables were selected based on the elements identified in the RBV theory and the Assets-ProcessesPerformance framework, as well as in the findings of previous studies, such as P. Liargovas and K. Skandalis (2008), E. Laitinen (2008), R. Asogwa (2009), B. Navaretti et al, (2011), T. Korankye and R. Adarquah (2013), F. A. Atanda (2014), F. A. Atanda et al, (2015), M. A. Afridi and M. E. Javaid (2015), C. Egbunike and C. Okerekeoti (2018), A. Onakoya (2018). The dependent variable was the competitiveness of a firm, whereas the firm-specific and environmental factors were the explanatory variables. The following procedures were carried out in order to analyze the data: the descriptive techniques were used to examine the features typical of the data, the sampled firms, the LC firms and the HC firms. Subsequently, multiple correlation was used to test for any incidence of the multicollinearity problem in the explanatory variables. This was to ascertain if all the identified variables should be included in the regression model, without resulting in spurious estimates. In addition, the time series properties of the data were examined by performing a partial autocorrelation test by using the Box-Jenkins statistics to test for the endogeneity problem in the 
Table 1 The chart of variables and measurement

\begin{tabular}{|c|c|c|c|}
\hline Variable & A priori & Explanation & Measurement \\
\hline $\begin{array}{l}\text { Firm } \\
\text { Competitiveness } \\
\text { (FMC) }\end{array}$ & & $\begin{array}{l}\text { This is the ability of a firm to create economic } \\
\text { value from sales, relative to other firms. }\end{array}$ & $\begin{array}{l}\text { The ratio of value added (EVA) to sales } \\
\text { revenue. EVA is the difference between } \\
\text { the output value and the input value. }\end{array}$ \\
\hline Firm age (AGE) & + & $\begin{array}{l}\text { This is the number of the years which a firm has } \\
\text { been incorporated for. Older firms may benefit } \\
\text { from reputation and long-term relationships. }\end{array}$ & $\begin{array}{l}\text { The natural logarithm of the number of } \\
\text { the years a firm has been in operation. }\end{array}$ \\
\hline Size (SZE) & + & $\begin{array}{l}\text { This is the competitive power of a firm. Smaller } \\
\text { firms are more volatile and riskier than larger } \\
\text { ones. }\end{array}$ & $\begin{array}{l}\text { The natural logarithm of the total } \\
\text { assets of a firm. }\end{array}$ \\
\hline Leverage (LEV) & - & $\begin{array}{l}\text { The extent to which a firm uses borrowed } \\
\text { money. A highly leveraged firm is at the risk of } \\
\text { liquidation. }\end{array}$ & The debts-to-the total liabilities ratio. \\
\hline Growth (GRW) & + & $\begin{array}{l}\text { The movement of a firm from one } \\
\text { development phase to another. A high rate } \\
\text { signifies investment opportunities. }\end{array}$ & The rates of change in sales revenue. \\
\hline Risk (RSK) & $-1+$ & $\begin{array}{l}\text { This is a risk inherent in a business, which } \\
\text { cannot be diversified. It is the variability in } \\
\text { returns (EBDIT) of each firm. }\end{array}$ & $\begin{array}{l}\text { The standard deviation of earnings } \\
\text { before depreciation, interests and } \\
\text { taxes (EBDIT). }\end{array}$ \\
\hline Liquidity (LIQ) & + & $\begin{array}{l}\text { The rate at which short-term indebtedness is } \\
\text { settled promptly. High liquidity refers to the } \\
\text { ability to quickly convert assets into cash. }\end{array}$ & $\begin{array}{l}\text { The ratio of the current assets to the } \\
\text { current liabilities (the current ratio). }\end{array}$ \\
\hline $\begin{array}{l}\text { Productive Assets } \\
\text { (AST) }\end{array}$ & + & $\begin{array}{l}\text { This is the extent to which the total assets of a } \\
\text { firm are physical, tangible and productive. }\end{array}$ & $\begin{array}{l}\text { The ratio of the fixed assets to the } \\
\text { total assets. }\end{array}$ \\
\hline $\begin{array}{l}\text { The employee } \\
\text { capacity (NOE) }\end{array}$ & + & $\begin{array}{l}\text { The total number of employees in a firm at a } \\
\text { point in time. }\end{array}$ & $\begin{array}{l}\text { The natural logarithm of the number of } \\
\text { employees. }\end{array}$ \\
\hline Profitability (PRT) & + & $\begin{array}{l}\text { The efficiency with which a firm uses its assets } \\
\text { to generate returns. }\end{array}$ & $\begin{array}{l}\text { The ratio of the EBIDT to sales } \\
\text { revenue. }\end{array}$ \\
\hline $\begin{array}{l}\text { The capital } \\
\text { expenditure of the } \\
\text { government (CAR) }\end{array}$ & + & $\begin{array}{l}\text { The economic infrastructures available in the } \\
\text { economy. }\end{array}$ & $\begin{array}{l}\text { The capital expenditure ofte } \\
\text { government as a proportion of the } \\
\text { GDP. }\end{array}$ \\
\hline Inflation (INF) & $+/-$ & Changes in price levels. & Prevailing inflation rates. \\
\hline $\begin{array}{l}\text { Developments in } \\
\text { the labor market } \\
(\text { LBM) }\end{array}$ & + & $\begin{array}{l}\text { Change of the labour force conpensation in the } \\
\text { economy. }\end{array}$ & $\begin{array}{l}\text { A conpensation paid to labour force as } \\
\text { a proportion of the GDP. }\end{array}$ \\
\hline $\begin{array}{l}\text { The cost of finance } \\
\text { (COF) }\end{array}$ & - & $\begin{array}{l}\text { The cost of servicing long-term debts } \\
\text { contracted by a firm. A high cost may deter } \\
\text { investments and reduce the income of a firm. }\end{array}$ & $\begin{array}{l}\text { Prevailing interest rates in the } \\
\text { economy. }\end{array}$ \\
\hline $\begin{array}{l}\text { The foreign } \\
\text { exchange policy } \\
(\text { FRX) }\end{array}$ & - & $\begin{array}{l}\text { This is the stance of the government on a } \\
\text { foreign-exchange market. A high rate may } \\
\text { increase costs and reduce the income of a firm. }\end{array}$ & $\begin{array}{l}\text { The natural logarithm of the prevailing } \\
\text { foreign-exchange rates. }\end{array}$ \\
\hline
\end{tabular}

Source: Authors 
dependent variable (the competitiveness of a firm) and the unit root tests using the four criteria (LevinLevin-Chu, Im-Pesaran-Shin, Augumented DickeyFuller and Philip-Peron) to determine the estimation technique appropriate for the data and the specified model. Since this study considered a large number of the explanatory variables, the multiple regression technique was found to be appropriate. The empirical results are presented in the tables and the same are discussed in the following section.

\section{EMPIRICAL RESULTS}

\section{Descriptive results}

Descriptive analysis showed the existence of the positive average value created during the periods, although the scattering of the economic values around the mean (i.e. the standard deviation) for the selected firms was high (Table 2). The HC firms engaged more employees than the LC firms, which means that the number of the employees might have contributed to the value creating potentials of the former comparing to the latter. The results further indicated the fact that the average age of the $\mathrm{HC}$ firms was lower compared to the LC firms. Also, there was a lower level of the revenue (sales) growth, the asset base and the productive assets for the HC firms compared to the LC firms. Therefore, there is the need to ascertain whether huge investments in tangible non-current assets necessarily lead to the high competitiveness of the firms, or not. Again, the LC firms were more liquid than the HC firms, which pointed to the fact that the former had more resources tied down in the current assets such as receivables and inventories than the latter. Moreover, there was an elevated level of the business risk of the $\mathrm{HC}$ firms compared to the average for the sample and the LC firms. This showed that there was the need for the empirical evidence of whether the firms that were aggressive in risk-taking were more competitive than the risk-averse firms. Also, using debts as a source of financing was higher in the LC firms than in the HC firms, which indicates that a highly-leveraged firm was likely to be a low performer than a low-leveraged firm. This might be due to the fact that a large proportion of the EVA created by the highly-leveraged firms will be used to service debts, which might threaten the sustainability of the firms even in the short run.

The data accounted for in Table 2 further provide information on the need to transform some of the explanatory variables in the regression model specified in this study, namely age, the employee capacity and the size of the firm. This was caused by the different means by which the variables were measured. The age of the firm was measured by the number of years and the employee capacity was measured by the number of employees, while the size of the firm was measured by the value of the company's total assets. These resulted in the high standard deviations obtained for the variables. Therefore, there is the need to reduce them to the same level as is the level of the other variables that were expressed in percentages. Consequently, the three explanatory variables were transformed by using a natural logarithm.

\section{Multicollinearity and the unit root test results}

Multicollinearity and the unit root test results are shown in the tables 3 and 4, respectively. The data in Table 3 show the low level of correlations among the explanatory variables pairwise, except for the relationship between CAR and the GDP; the FRX and INF, and the FRX and the LBM that were moderate, but not up to 0.8 benchmarked by Lewis-Beck (1993) for the existence of multicollinearity. However, high correlation levels between the GDP and the FRX $(r=0.805, P<.001)$, and between the GDP and the LBM $(r=0.917, P<.001)$ were found.

Similar results were obtained when the sample data were divided into the low- and high-competition firms. The correlations between the GDP and the FRX and between the GDP and the LBM for the highand low-competition firms, respectively, were 0.806 
Table 2 The descriptive statistics of the competitiveness of the firms and the firm-specific factors

\begin{tabular}{|c|c|c|c|c|c|c|c|c|c|c|}
\hline Statistics & AGE & AST & FMC & GRW & LEV & LIQ & NOE & PRT & RSK & SZE \\
\hline \multicolumn{11}{|l|}{ All Firms } \\
\hline Mean & 39.455 & 0.387 & 25.193 & 0.263 & 0.183 & 1.558 & 968.146 & 3.957 & $-1.73 \mathrm{E}-05$ & 10208.95 \\
\hline Standard dev. & 20.534 & 0.207 & 18.297 & 0.455 & 0.247 & 5.923 & 1381.29 & 24.996 & 3.118 & 30550.18 \\
\hline Maximum & 133.00 & 0.999 & 154.161 & 3.846 & 0.990 & 229.507 & 9475.00 & 66.198 & 58.512 & 515063.8 \\
\hline Minimum & 1.000 & 0.005 & -165.253 & -0.838 & -0.476 & -0.226 & 3.000 & -360.266 & -37.092 & 3.896 \\
\hline No. of obs. & 1535 & 1535 & 1535 & 1467 & 1535 & 1535 & 1535 & 1535 & 1535 & 1535 \\
\hline \multicolumn{11}{|c|}{ High-competition firms } \\
\hline Mean & 39.013 & 0.384 & 33.215 & 0.255 & 0.179 & 1.551 & 1122.34 & 8.270 & $-3.46 \mathrm{E}-05$ & 10071.87 \\
\hline Standard dev. & 22.018 & 0.209 & 15.084 & 0.428 & 0.235 & 1.068 & 1578.27 & 19.462 & 1.312 & 24608.02 \\
\hline Maximum & 133.000 & 0.999 & 154.16 & 3.113 & 0.987 & 15.247 & 9475.00 & 43.964 & 15.269 & 235701.20 \\
\hline Minimum & 1.000 & 0.005 & -55.058 & -0.838 & 0.000 & 0.002 & 3.000 & -150.58 & -6.312 & 3.896 \\
\hline No. of obs. & 769 & 769 & 769 & 735 & 769 & 769 & 769 & 769 & 769 & 769 \\
\hline \multicolumn{11}{|c|}{ Low-competition firms } \\
\hline Mean & 39.899 & 0.390 & 17.139 & 0.2720 & 0.186 & 1.565 & 813.363 & -0.372 & $4.41 \mathrm{E}-08$ & 10346.56 \\
\hline Standard Dev. & 18.932 & 0.205 & 17.698 & 0.481 & .258 & 8.319 & 1130.25 & 28.899 & 4.216 & 35546.30 \\
\hline Maximum & 115.000 & 0.999 & 77.725 & 3.846 & 0.990 & 229.507 & 5862.00 & 66.198 & 58.512 & 515063.8 \\
\hline Minimum & 4.000 & 0.006 & -165.253 & -0.791 & -0.476 & -0.226 & 9.000 & -360.266 & -37.092 & 5.563 \\
\hline No. of obs. & 766 & 766 & 766 & 732 & 766 & 766 & 766 & 766 & 766 & 766 \\
\hline
\end{tabular}

Source: Authors

and 0.919 ; and 0.854 and 0.916 at the $1 \%$ significance level. Since the issue of multicollinearity is very controversial, the results gave rise to the fact that the exogenous variable (the GDP) that demonstrated a high correlation with the other variables should not be included in the same estimated regression equation models. The linear regression expressed in Equation (1) was, therefore, remodeled accordingly by removing the GDP from the equation.

In addition, the data given in Table 4 show that the capital-expenditure ratio, developments in the labor market, the employee capacity and risk were integrated of order 1 , and needed to be included in the regression model at the first difference, whereas the other variables were integrated of zero or stationary at the level, hence being included at the level in the regression models. These results indicate the fact that the Ordinary Least Square (OLS) estimation method could not be used, but a higher-level estimation technique such as Autoregressive Distributed Lag (ARDL) should be used instead.

\section{Pre-estimation diagnostic results}

The results obtained from the Box-Jenkins Q-statistic test indicated that there was the endogeneity problem, because the competitiveness of a firm (measured by the proportion of economic value added to the sales revenue of a firm in relation to other firms) followed an autoregressive $\operatorname{AR}(2)$ function after two periods and for all firms (Table A1 in the Appendix). The variable also followed an autoregressive $\mathrm{AR}(1)$ function after one period for the HC firms and the LC firms, respectively, when the data were disaggregated (Tables A2 and A3 in the Appendix). The partial autocorrelation (PAC) column in the tables shows that the Q-statistic turns to less than 0.1 after the second period for the data of all the firms, and after the first period for the data of the $\mathrm{HC}$ firms and the LC firms, respectively. Therefore, a two-period lagged FMC was included among the explanatory variables in the model of the competitiveness of a firm for all the firms, whereas a one-period lagged FMC was included in the model for the high- and 
Table 3 The multiple correlation results

\begin{tabular}{|c|c|c|c|c|c|c|c|c|c|c|c|c|c|c|c|c|}
\hline Variable & AST & AGE & FMC & GRW & LEV & LIQ & NOE & PRT & RSK & SZE & CAR & $\mathrm{COF}$ & FRX & GDP & INF & LBM \\
\hline AST & 1.0000 & & & & & & & & & & & & & & & \\
\hline \multirow[t]{2}{*}{ AGE } & 0.1370 & 1.0000 & & & & & & & & & & & & & & \\
\hline & .000 & & & & & & & & & & & & & & & \\
\hline \multirow[t]{2}{*}{ FMC } & 0.0088 & -0.0597 & 1.0000 & & & & & & & & & & & & & \\
\hline & .731 & .019 & & & & & & & & & & & & & & \\
\hline \multirow[t]{2}{*}{ GRW } & -0.1173 & -0.1537 & 0.0827 & 1.0000 & & & & & & & & & & & & \\
\hline & .000 & .000 & .002 & & & & & & & & & & & & & \\
\hline \multirow[t]{2}{*}{ LEV } & -0.0126 & -0.1387 & 0.0292 & 0.1057 & 1.0000 & & & & & & & & & & & \\
\hline & .621 & .000 & .252 & .000 & & & & & & & & & & & & \\
\hline \multirow[t]{2}{*}{ LIQ } & -0.0392 & -0.0509 & 0.0305 & -0.0016 & 0.0021 & 1.0000 & & & & & & & & & & \\
\hline & .125 & .046 & .233 & .951 & .935 & & & & & & & & & & & \\
\hline \multirow[t]{2}{*}{ NOE } & 0.0723 & 0.3070 & 0.1040 & 0.0335 & -0.0552 & -0.0158 & 1.0000 & & & & & & & & & \\
\hline & .005 & .000 & .000 & .200 & .031 & .536 & & & & & & & & & & \\
\hline \multirow[t]{2}{*}{ PRT } & -0.2295 & -0.0269 & 0.6199 & 0.2147 & 0.0481 & 0.0509 & 0.1153 & 1.0000 & & & & & & & & \\
\hline & .000 & .293 & .000 & .000 & .060 & .046 & .000 & & & & & & & & & \\
\hline \multirow[t]{2}{*}{ RSK } & -0.0423 & 0.0675 & 0.2037 & 0.0462 & -0.0308 & -0.0114 & -0.0103 & 0.2901 & 1.0000 & & & & & & & \\
\hline & .098 & .008 & .000 & .077 & .228 & .656 & .687 & .000 & & & & & & & & \\
\hline \multirow[t]{2}{*}{ SZE } & 0.1485 & 0.1509 & 0.0075 & -0.0363 & -0.0457 & -0.0223 & 0.1817 & 0.0703 & 0.1206 & 1.0000 & & & & & & \\
\hline & .000 & .000 & .769 & .165 & .073 & .382 & .000 & .006 & .000 & & & & & & & \\
\hline \multirow[t]{2}{*}{ CAR } & -0.1754 & -0.1959 & -0.0142 & 0.0602 & 0.0432 & 0.0181 & 0.0776 & 0.0627 & -0.1009 & -0.2087 & 1.0000 & & & & & \\
\hline & .000 & .000 & 0.578 & .021 & .091 & .478 & .002 & .014 & .000 & .000 & & & & & & \\
\hline \multirow[t]{2}{*}{$\mathrm{COF}$} & -0.1005 & -0.1705 & 0.0509 & 0.1164 & 0.1378 & 0.0838 & 0.0808 & 0.0378 & -0.1226 & -0.1609 & 0.0874 & 1.0000 & & & & \\
\hline & .000 & .000 & .046 & .000 & .000 & .001 & .002 & .138 & .000 & .000 & .001 & & & & & \\
\hline \multirow[t]{2}{*}{ FRX } & 0.2384 & 0.2975 & -0.1249 & -0.2258 & -0.1996 & -0.0596 & -0.1352 & -0.1644 & 0.1743 & 0.2642 & -0.4957 & -0.4951 & 1.0000 & & & \\
\hline & .000 & .000 & .000 & .000 & .000 & .020 & .000 & .000 & .000 & .000 & .000 & .000 & & & & \\
\hline \multirow[t]{2}{*}{ GDP } & 0.2302 & 0.3054 & -0.0474 & -0.1759 & -0.1339 & -0.0339 & -0.1303 & -0.0693 & 0.2186 & 0.3404 & -0.6809 & -0.4536 & 0.8051 & 1.0000 & & \\
\hline & .000 & .000 & .063 & .000 & .000 & .184 & .000 & .007 & .000 & .000 & .000 & .000 & .000 & & & \\
\hline \multirow[t]{2}{*}{ INF } & -0.1872 & -0.1767 & 0.1216 & 0.2736 & 0.1157 & 0.0416 & 0.0931 & 0.1520 & -0.0889 & -0.1430 & 0.0921 & 0.3449 & -0.6095 & -0.4581 & 1.0000 & \\
\hline & .000 & .000 & .000 & .000 & .000 & .103 & .000 & .000 & .001 & .000 & .000 & .000 & .000 & .000 & & \\
\hline \multirow[t]{2}{*}{ LBM } & 0.1831 & 0.2621 & -0.0188 & -0.1394 & -0.1009 & -0.0197 & -0.1114 & -0.0078 & 0.2304 & 0.3354 & -0.5375 & -0.4308 & 0.6155 & 0.9172 & -0.3282 & 1.0000 \\
\hline & .000 & .000 & .461 & .000 & .000 & .441 & .000 & .761 & .000 & .000 & .000 & .000 & .000 & .000 & .000 & \\
\hline
\end{tabular}

Source: Authors, Included observations: 1,564

low-competition firms, respectively. As a result, the use of the ARDL estimation technique was no longer feasible and the GMM technique was adopted in order to estimate the three models. To obtain the GMM estimates, the moment condition was written as the orthogonality condition between the expression including the parameters to be estimated and the set of the instrumental variables that included the lagged explanatory variables. This corrects endogeneity by transforming instruments so as to make them uncorrelated with the error term and improve efficiency.

\section{REGRESSION RESULTS}

The detailed results obtained from the GMM estimation were reported in the three columns of 
Table 4 The unit root test results

\begin{tabular}{|c|c|c|c|c|c|c|c|c|c|c|}
\hline \multirow{2}{*}{ Variable } & & \multicolumn{2}{|c|}{ LLC } & \multicolumn{2}{|c|}{ IPS } & \multicolumn{2}{|c|}{ ADF } & \multicolumn{2}{|c|}{ PP } & \multirow{2}{*}{$\begin{array}{c}\text { Order of } \\
\text { Integration }\end{array}$} \\
\hline & & Stat. & Prob. & Stat. & Prob. & Stat. & Prob. & Stat. & Prob. & \\
\hline FMC & Level & -6.142 & .000 & -6.469 & .000 & 256.214 & .000 & 427.771 & .000 & $\mathrm{I}(0)$ \\
\hline $\ln (A G E)$ & Level & -42.02 & .000 & -365.8 & .000 & 15215.0 & .000 & 14699.0 & .000 & $\mathrm{I}(0)$ \\
\hline AST & Level & -2.385 & .009 & -3.294 & .001 & 195.557 & .001 & 214.247 & .000 & $\mathrm{I}(0)$ \\
\hline \multirow[t]{2}{*}{ CAR } & Level- & 3.623 & .999 & 2.368 & .991 & 61.872 & 1.00 & 72.327 & 1.00 & $\mathrm{I}(1)$ \\
\hline & $1^{\text {st }}$ Diff. & -16.94 & .000 & -11.91 & .000 & 376.246 & .000 & 878.979 & .000 & \\
\hline $\mathrm{COF}$ & Level & -10.47 & .000 & -4.771 & .000 & 184.453 & .004 & 733.524 & .000 & $\mathrm{I}(0)$ \\
\hline $\ln (\mathrm{FRX})$ & Level & -27.45 & .000 & -18.97 & .000 & 601.522 & .000 & 2107.67 & .000 & $\mathrm{I}(0)$ \\
\hline GRW & Level & -12.52 & .000 & -11.75 & .000 & 390.981 & .000 & 636.227 & .000 & $\mathrm{I}(0)$ \\
\hline INF & Level & -6.660 & .000 & -8.840 & .000 & 291.945 & .000 & 214.040 & .000 & $\mathrm{I}(0)$ \\
\hline \multirow[t]{2}{*}{$\ln (\mathrm{LBM})$} & Level & 0.348 & 1.00 & 12.246 & 1.00 & 9.544 & 1.00 & 4.493 & 1.00 & $\mathrm{I}(1)$ \\
\hline & $1^{\text {st }}$ Diff. & -26.57 & .000 & -28.69 & .000 & 926.75 & .000 & 1510.75 & .000 & \\
\hline LEV & Level & -5.618 & .000 & -4.380 & .000 & 221.347 & .000 & 424.022 & .000 & $\mathrm{I}(0)$ \\
\hline LIQ & Level & -16.74 & .000 & -8.508 & .000 & 507.592 & .000 & 482.396 & .000 & $\mathrm{I}(0)$ \\
\hline \multirow[t]{2}{*}{$\ln (\mathrm{NOE})$} & Level & -0.088 & .465 & 1.863 & .969 & 136.140 & .481 & 107.065 & .968 & $\mathrm{I}(1)$ \\
\hline & $1^{\text {st }}$ Diff. & -11.02 & .000 & -11.66 & .000 & 404.901 & .000 & 726.052 & .000 & \\
\hline PRT & Level & -3.833 & .000 & -4.842 & .000 & 229.474 & .000 & 322.457 & .000 & $\mathrm{I}(0)$ \\
\hline \multirow[t]{2}{*}{$\ln (\mathrm{RSK})$} & Level & 8.974 & 1.00 & 7.104 & 1.00 & 128.995 & .652 & 160.346 & .076 & $\mathrm{I}(1)$ \\
\hline & $1^{\text {st }}$ Diff. & -9.371 & .000 & -14.94 & .000 & 527.955 & .000 & 1513.48 & .000 & \\
\hline $\ln (\mathrm{SZE})$ & Level & -11.61 & .003 & -3.336 & .001 & 224.351 & .004 & 283.438 & .002 & $\mathrm{I}(0)$ \\
\hline
\end{tabular}

Source: Authors

Table 5. The first shows the results for all the firms in the sample, the second reports the results for the HC firms, whereas the third was accounts for the results for the LC firms. A quick glance at the results in the first model reveals the fact that the two-period lagged competitiveness of the firms has a significant positive effect on the current year competitiveness of the firms. It also shows that a total of the seven firmspecific factors and the five environmental factors have a significant effect on the competitiveness of the firms during the periods. While the effect of the capital expenditure ratio of the government, the foreign exchange rates and the inflation rates on the competitiveness of the firms is positive, the effect of the interest rates and developments in the labor market is negative. These results, however, contrast the findings of F. A. Atanda et al, (2015) with the exception of the foreign-exchange rates. The exclusion of financial companies and the longer periods covered by this study might have accounted for the differences, since the same estimation technique was used.

In addition, the firms' age, productive assets, profitability and business risk have a significant positive effect on the competitiveness of the firms, whereas sales growth, the employee capacity and the size of the firm have a significant negative effect. The significant results for profitability, risk and growth are supportive of the findings of E. Laitinen (2008), but contrast the findings of F. A. Atanda (2014), in addition to the firms' age, size, employee capacity and productive assets. The contrast might be due to the differences in the used estimation techniques. In the 
same vein that the differences between the companies and the time periods covered by the previous studies accounted for the differences in the results, categorizing the Nigerian non-financial quoted firms into high- and low-competition firms was expected to bring about different results. The data shown in
Table 5 provide the evidence of the varying impact of the factors that influenced the competitiveness of the $\mathrm{HC}$ and LC firms in the non-financial sector of the Nigerian economy.

The data for the HC firms (Column 5) and the LC firms (Column 6) reveal the fact that the one-year

Table 5 The GMM regression results

\begin{tabular}{|c|c|c|c|c|c|}
\hline & Variable & A priori Sign & $\begin{array}{c}\text { Model } 1 \\
\text { (All Firms) }\end{array}$ & $\begin{array}{c}\text { Model } 2 \\
\text { (HC Firms) }\end{array}$ & $\begin{array}{c}\text { Model } 3 \\
\text { (LC Firms) }\end{array}$ \\
\hline \multirow{2}{*}{$\begin{array}{l}\text { Lagged dependent } \\
\text { variable }\end{array}$} & $\mathrm{FMC}(-1)$ & + & $\begin{array}{c}0.1798 * * \\
{[13.507]}\end{array}$ & $\begin{array}{c}0.3554 * * \\
{[5.809]}\end{array}$ & $\begin{array}{l}0.0624^{*} \\
{[2.357]}\end{array}$ \\
\hline & $\operatorname{FMC}(-2)$ & + & $\begin{array}{c}0.0581 * * \\
{[5.234]}\end{array}$ & - & - \\
\hline \multirow{9}{*}{ Firm-specific factors } & $\ln (\mathrm{AGE})$ & + & $\begin{array}{c}0.2028 * * \\
{[8.137]}\end{array}$ & $\begin{array}{c}14.0510 * \\
{[1.763]}\end{array}$ & $\begin{array}{l}-5.2960 \\
{[-1.034]}\end{array}$ \\
\hline & AST & + & $\begin{array}{c}.10 .3315^{* *} \\
{[7.890]}\end{array}$ & $\begin{array}{c}15.7021 * \\
{[2.369]}\end{array}$ & $\begin{array}{c}6.7253 \\
{[0.808]}\end{array}$ \\
\hline & GRW & + & $\begin{array}{c}-1.6882 * * \\
{[-3.427]}\end{array}$ & $\begin{array}{l}-2.5068 \\
{[-1.490]}\end{array}$ & $\begin{array}{l}-3.8750 * \\
{[-2.188]}\end{array}$ \\
\hline & LEV & - & $\begin{array}{l}-0.0356 \\
{[-0.028]}\end{array}$ & $\begin{array}{l}-4.0598 \\
{[-1.479]}\end{array}$ & $\begin{array}{l}0.1583 \\
{[0.057]}\end{array}$ \\
\hline & LIQ & + & $\begin{array}{c}0.1792 \\
{[0.842]}\end{array}$ & $\begin{array}{l}0.9541 \\
{[1.255]}\end{array}$ & $\begin{array}{l}-2.0617 \\
{[-1.278]}\end{array}$ \\
\hline & $\ln (\mathrm{NOE})$ & + & $\begin{array}{c}-3.8425 * * \\
{[-5.600]}\end{array}$ & $\begin{array}{l}-3.6212 \\
{[-1.113]}\end{array}$ & $\begin{array}{c}-4.7482 * * \\
{[-5.465]}\end{array}$ \\
\hline & PRT & + & $\begin{array}{c}0.3689 * * \\
{[36.220]}\end{array}$ & $\begin{array}{c}0.2593^{* *} \\
{[3.333]}\end{array}$ & $\begin{array}{c}0.4827^{* *} \\
{[8.510]}\end{array}$ \\
\hline & RSK & + & $\begin{array}{c}0.5226 * * \\
{[8.163]}\end{array}$ & $\begin{array}{l}1.9333 \\
{[1.013]}\end{array}$ & $\begin{array}{c}0.4812 * * \\
{[2.877]}\end{array}$ \\
\hline & $\ln (\mathrm{SZE})$ & + & $\begin{array}{c}-2.1864 * * \\
{[-6.841]} \\
\end{array}$ & $\begin{array}{c}-2.5926 \\
{[-1.1059]} \\
\end{array}$ & $\begin{array}{l}2.1920 * \\
{[2.299]} \\
\end{array}$ \\
\hline \multirow{5}{*}{$\begin{array}{l}\text { Macroeconomic } \\
\text { factors }\end{array}$} & CAR & + & $\begin{array}{c}1.8836^{*} \\
{[2.171]}\end{array}$ & $\begin{array}{c}12.03644^{*} \\
{[2.491]}\end{array}$ & $\begin{array}{l}-1.0873 \\
{[-0.260]}\end{array}$ \\
\hline & $\mathrm{COF}$ & - & $\begin{array}{c}-0.0750 * \\
{[-2.112]}\end{array}$ & $\begin{array}{l}-0.2180 * \\
{[-2.499]}\end{array}$ & $\begin{array}{c}0.1521 \\
{[1.665]}\end{array}$ \\
\hline & $\ln (\mathrm{FRX})$ & - & $\begin{array}{c}1.8922 * * \\
{[6.335]}\end{array}$ & $\begin{array}{l}2.4291 \\
{[0.831]}\end{array}$ & $\begin{array}{l}-0.4864 \\
{[-0.858]}\end{array}$ \\
\hline & INF & $-1+$ & $\begin{array}{c}0.0772 * * \\
{[9.309]}\end{array}$ & $\begin{array}{l}0.0661 \\
{[1.098]}\end{array}$ & $\begin{array}{c}0.1004^{* *} \\
{[8.633]}\end{array}$ \\
\hline & $\ln (\mathrm{LBM})$ & + & $\begin{array}{c}-2.7112 * * \\
{[-2.943]}\end{array}$ & $\begin{array}{c}-8.8972 \\
{[-0.807]} \\
\end{array}$ & $\begin{array}{l}0.4803 \\
{[0.243]}\end{array}$ \\
\hline J-statistic & & & 42.3659 & 15.4596 & 14.5102 \\
\hline P-value (J-stat.) & & & 0.8274 & 0.6930 & 0.7532 \\
\hline Instrument Rank & & & 56 & 27 & 27 \\
\hline No. of observation & & & 1,194 & 599 & 595 \\
\hline Cross-section & & & 68 & 34 & 34 \\
\hline
\end{tabular}

Note: The figures in [] are t-statistics. * and ** are the $5 \%$ and $1 \%$ significance levels, respectively

Source: Authors 
lagged competitiveness of the firms positively and significantly contributes to the current year competitiveness of the firms. These show that there is a habit formation in the competitiveness of the firms during the period. However, a stronger habit was detected for the HC firms than for the LC firms, and some factors must have been responsible for that. The firm-specific factors such as the firm's age, productive assets and profitability, as well as the capital expenditure ratio of the government had a significant positive effect on the level of the competitiveness of the HC firms, whereas the prevailing interest rates had a significant negative effect. The results imply the fact that the older firms were more competitive in value creation than the younger firms, whereas in the case of the LC firms, the younger firms were more competitive than the older firms, although the result was not significant. A unit increase in age led to an increase of about 14 percent growth in the competitiveness of the firms, whereas an increase of one percent in profitability caused the competitiveness of the firms to significantly increase by 0.26 percent. Also, the more productive the assets of the HC firms, the greater the competitiveness of the firms. A $1 \%$ increase in the productive assets led to an increase of about 15 percent in the level of the competitiveness of the HC firms, which was an indication of the level of the productivity of the firms' assets. This result fails to provide support to the findings of M. A. Afridi and M. E. Javaid (2015), who established a significant negative effect of productive assets on the competitiveness of the firms operating in the textile industry in Pakistan. However, an increase of one unit in interest rates led to a significant 0.22 percent reduction of in the competitiveness of the firms.

A significant positive effect of the firm's profitability and risk and the size of the firm on the level of the competitiveness of the LC firms was found. These results confirm the findings of E. Laitinen (2008) and R. Asogwa (2009). So, the higher the risk, the higher the level of the competitiveness of the LC firms, ceteris paribus. The HC firms that had a lesser business risk performed better in creating economic value compared to the LC firms. This shows that the LC firms were more aggressive in risk-taking than the $\mathrm{HC}$ firms, and that the business activities engaged in by the LC firms were characterized by a higher level of variability in returns than that of the $\mathrm{HC}$ firms. While the size of the firm contributed significantly and positively to the level of the competitiveness achieved by the LC firms, its effect on that of the HC firms was insignificant, but positive. This means that the asset base was not an important factor for the HC firms in their achieving a high level of competitiveness as it was for the LC firms.

Despite the expected positive impact of the employee capacity and sales growth, there were the negative effects of these factors on the competitiveness of the firms significant at less than 1 and 5 percent, respectively, for the LC firms. While the impact of the employee capacity was significant at less than 1 percent for the LC firms, the impact was, however, not significant for the HC firms, even at a 10 percent level. The negative effect of the employee capacity was an indication of the fact that the increased labor force was not justified, or that the relevant professionals that could have brought about an increased level of competitiveness had not been engaged. It might also be indicative of the fact that the LC firms engaged themselves in more labor-intensive economic activities than the HC firms during the period.

Again, the negative effect of sales growth, which contrasted the a priori expectation, was an indication of the degree of the aggressiveness of the LC firms in growing sales revenue with a negative impact on their competitiveness. Most firms must have engaged themselves in the economic activities that had destroyed, rather than created, positive economic value, or that the level of the economic activities which the firms had engaged themselves in had not led to high economic value, which had made them be low-competition firms. The higher mean value of sales growth for the LC firms than the HC firms had really accounted for a higher magnitude and a significant impact of sales growth on the level of the competitiveness achieved by the LC firms in comparison with that of the HC firms. Increased sales growth was expected to lead to a high level of competitiveness. However, sales growth was found to have a significant negative effect on the competitiveness of the firms, which was indicative of 
the fact that the LC firms were likely experiencing the problem of overtrading, i.e. using too many assets to trade. A cursory look into the composition of the total assets of the firms reveals a high level of the current assets such as inventories and accounts receivables. As sales growth was increasing, the level of competitiveness was decreasing at a very significantly high rate.

At the macro level, the level of the competitiveness achieved by the LC firms and the HC firms was determined as significant, not only by the capital expenditure ratio of the government and the prevailing interest rates, but also by inflation. Of course, the magnitudes and directions of the impact of these factors varied. Inflation can have a dual effect on the performance of a firm because it can cause a disincentive to investments as a result of high operation costs and can lead to increased performance, since inflation is often referred to as changes in the price level. However, the results show that the factor has a positive impact on the competitiveness of the $\mathrm{HC}$ firms and the LC firms, but with a greater significant effect on that of the LC firms. Surprisingly, the interest rates have a significant negative impact on the competitiveness of the $\mathrm{HC}$ firms, but a significant positive effect on that of the LC firms. A $1 \%$ increase in the interest rates led to a significant reduction of about 0.22 percent in the competitiveness of the $\mathrm{HC}$ firms, but an increase of about 0.15 percent in the competitiveness of the LC firms. This shows that the interest rates played dual roles in competitiveness and that the LC firms had better ways to absorb the high cost of financing than the HC firms, so that they achieved a higher level of competitiveness.

The other environmental factor that distinguished the HC firms from the LC firms was the capital expenditure ratio of the government. A significant and highly positive impact of the factor on the competitiveness of the HC firms was found. However, the factor played a detrimental role when speaking about the competitiveness of the LC firms; it was not significant, though. This might be the consequence of the types of businesses or the economic activities engaged in by the firms, which were not significantly affected by government policies. Although the exchange rates and developments in the labor market had a significant effect for all the firms, the results indicated an insignificant effect of the factors on the level of the competitiveness of the HC firms and the LC firms separately.

\section{CONCLUSION}

In this study, panel data were used to investigate the influence of firm-specific and environmental factors on the competitiveness of non-financial quoted firms in Nigeria. The competitiveness of the firms, which was computed as a proportion of economic value added to sales revenue, was expressed as the function of its lagged value, a total of nine firm-specific factors and five environmental factors. Descriptive, inferential and econometric tools were used to analyze the study data. The descriptive results showed the diverse features of the HC firms and the LC firms with regard to their levels of competitiveness and firm-specific characteristics.

The results obtained from the econometric analysis indicated the fact that the differences in the basic characteristics of the firms explained the differences in the competitiveness of the firms. The most important factors that can be used to explain the high level of competitiveness included the firms' age, productive assets, profitability, the capital expenditure ratio of the government and the cost of financing (interest rates). While the firms' age, assets tangibility and profitability, and the capital expenditure ratio of the government positively contributed to the achievement of a high level of competitiveness, the cost of financing impedes their potentials. In contrast, while profitability, business risk, the size of the firm and the inflation rates positively contribute to the level of the competitiveness achieved by the LC firms, sales growth and the employee capacity reduce their potentials. The results led to the rejection of the null hypothesis that there is no significant influence of firm-specific and environmental factors on the level of the competitiveness achieved by the $\mathrm{HC}$ and the LC non-financial listed firms in Nigeria. Therefore, a conclusion is drawn that firm-specific 
and environmental factors have both beneficial and detrimental effects on the abilities of the firms to be competitive.

The results portend many policy implications for firms and the government in Nigeria. Firstly, managers, regulators and policy makers will better understand the interactions of firms' characteristics and macroeconomic factors regarding the level of the competitiveness achieved by the non-financial listed firms in Nigeria. The interactions indicated that the managers of LC firms need to be more aggressive in searching for the opportunities that are high in value addition and profitability, since a high discrepancy was found between the average competitiveness and the profitability levels of the firms compared to their HC counterparts.

Secondly, the results showed that the HC firms had failed to leverage on the resources at their disposal (the assets and the employees) in order to achieve high competitiveness, which did not support the position of the resources-based view theory that the internal environment (resources, strategies, structures, etc.) of firms assist them to achieve high competitiveness. However, the significant results of the capacities of the HC firms (expressed in terms of the reputation built over a number of the years of their incorporation, efficiency in the use of the resource-profitability and asset structures) regarding the competitiveness of the firms and the results for the LC firms regarding profitability and business risk indicated support for the resource-based view theory. Again, the results regarding the sales growth potentials of the LC firms were not supportive of the position of the theory that a firm's capabilities in transforming its resources help it achieve economic gains. The significant negative effect of sales growth for the LC firms and its negative, but insignificant, effect for the HC firms practically showed that all the firms engaged in some economic activities had not enhanced their competitiveness levels during the period. Again, the low level of profitability for both the HC firms and the LC firms was an indication of the need for efficient resource utilization and cost reduction or control, or both. The $\mathrm{HC}$ firms need to be more aggressive in sales either through sales promotion or direct marketing, given the fact that they have potentials for creating higher value from economic activities than the LC firms do.

Thirdly, the descriptive results showed that the LC firms had a marginal higher mean asset tangibility with a smaller standard deviation than the HC firms. However, the factor did not significantly affect the competitiveness of the LC firms, which was an indication of the low level of the fixed tangible assets that may lead to a high level of competitiveness. The investment policies of the selected firms should therefore be looked into. The results of the significant positive influence of the size of the firm on the competitiveness of the LC firms also supported the need for more investment opportunities. Also, the significant negative impact of sales growth on the competitiveness of the firms pointed to the fact that the LC firms should examine their trade and credit policies so as to control slow-moving or outdated stocks and overstocking, and prevent the eventual cash flow problem and liquidation. Moreover, the negative effect of the employee capacity on the competitiveness of the LC firms called for a review of the policies on the type, number and quality of the employees engaged by the firms. An emphasis should be placed on the key professionals that can significantly contribute to the value creating potentials of the firms. The value appropriation and retention, as well as remuneration, policies of the firms should also be looked into.

Fourthly, a part of the environmental influences that a firm should address in the Nigerian economic system is the rising and unstable pricing system (inflation), foreign-exchange fluctuations, social and economic infrastructures, which are always inadequate, a high cost of financing as a result of sky-rocketing interest rates, and developments in the labor market that have led to an increased workers' remuneration since 2001. Although the overall results show that the capital expenditure of the government intended to address inadequate infrastructures, foreign-exchange rates and inflation rates has positively contributed to the competitiveness of the firms, the results for the $\mathrm{HC}$ firms indicate the fact that the firms failed to deal with the fluctuations in foreign-exchange rates, the cost of financing, inflation rates and developments in 
the labor market during the period covered by this study. Therefore, all the firms need to examine their strategies and resources deployed for dealing with instability in the economic environment. The fact that the capital expenditure of the government had a significant positive impact on the competitiveness achieved by the HC firms was indicative of the fact that physical infrastructures were still a 'sin-quanon' for the performance of the private sector. The government should, therefore, continue with its efforts in increasing expenditures on social and economic infrastructures (education, power and roads), as has been reflected in annual budgets in recent times, and their successful implementation, so that an improvement can be made in economic activities and a higher level of the competitiveness of firms in Nigeria. It is also important that the economic policies issued by the government and relating to the financial sector should encourage investments in the critical industrial sectors. The interest rate should be pegged at a single-digit rate, since it was found to be detrimental to the high competitiveness of firms.

There are some limitations inherent in this study, one part of which imply that, out of the various elements pointed to by resource-based view theory and the assets-processes-performance framework (resources, strategies (operations and marketing), technology, innovations, capabilities, structures, relationships management, brands and competencies), only resources and capabilities were included in the model of the competitiveness of firms. For example, as a part of a firm's strategies, the employee mix, rather than the number of employees, may be included. The employee mix points to the quality of the staff rather than their quantity, and a mix of more experienced and professional staff rather than a mix of unskilled or semi-skilled employees will provide the firm with more capabilities than if the firm were smaller. According to resource-based theory, a firm with a relatively small amount of resources, but with a high ambition to achieve competitiveness may in fact leverage on the resources to have greater outputs from smaller inputs and will be able to increase its resources if using the resources effectively and efficiently. This also shows that the size of resources does not matter. This study did not consider the industry, the firms' ambitions, the technology level, brands and relationships management in the model, either. However, researchers' major consideration will be how to measure variables such as brands, innovation, the technology level and the ambition of a firm. Again, a firm's openness to trade, which can be measured by the ratio of the trade credits used by the firm during a period of time over the trade credits given to its own customers was not included. A firm's use of more trade credits than it gives is an internal source of financing at a low cost or at no cost at all, which may consequently increase the firm's capacity to be more competitive. Besides, other measures, apart from EVA, such as market shares, productivity and customer satisfaction, can be used to measure the competitiveness of a firm. In addition, there are many other macroeconomic variables, such as the gross domestic product, money supply and developments in the capital markets that are not included in this study due to the multicollinearity problem. Further studies should endeavor to include these variables in their models.

\section{REFERENCES}

Abernethy, M., \& Lillis, A. (1995). The impact of manufacturing flexibility on management control system design. Accounting, Organization and Society, 20(4), 241-258. doi.org/10.1016/0361-3682(94)e0014-L

Adenikinju, A. (2005). Productivity performance in developing countries: Country case studies Nigeria. PAPER - Drivers of Firm Competitiveness- corrected.docx, UNIDO.

Afridi, M. A., \& Javaid, M. E. (2015). Determinants of competitiveness in textile industry of Pakistan. International Letters of Social and Humanistic Sciences, 61, 105-115. doi. org/10.18052/www.scipress.com/ilshs.61.105

Akalu, M. (2002). Measuring and ranking value drivers. A Discussion Paper, The Timbergen Institute for Economic Research of the Erasmus University, Amsterdam.

Akben-Selcuk, E. (2016). Factors affecting firm competitiveness: Evidence from an emerging market. International Journal of Financial Studies, 4(9), 1-10. doi:10.3390/ijfs4020009 
Ambastha, A., \& Momaya, K. (2006). Competitiveness of firms: Review of theory, frameworks and models. Singapore Management Review, 26(1), 45-61.

Asogwa, R. (2009July). Measuring the determinants of value creation for publicly listed banks in Nigeria: A random effects probit (REP) model analysis. Paper presented at the 14th Annual Conference on Econometric Modeling for Africa, held at Cape Town, South Africa.

Atanda, F. A.(2014). Valuecreationandappropriation in the Nigerian non-financial quoted companies. An unpublished doctorate thesis submitted to the Department of Management and Accounting, Obafemi Awolowo University, Nigeria.

Atanda, F. A., \& Asaolu, T. (2015). Developments in value creation and appropriation of Nigerian non-financial quoted companies. British Journal of Economics, Management and Trade, 9(1), 1-13. doi:10.9734/bjemt/2015/18640

Atanda, F. A., Asaolu, T., \& Oyerinde, A. (2015). Macroeconomic variables and value creation in the Nigerian quoted companies. International Journal of Economics and Finance, 7(6), 252-262. doi:10.5539/ijef.v7n6p252

Barney, J. (1991). Firm resources and sustained competitive advantage. Journal of Management, 17(1), 99-120.

Booth, L. (1998 October). What drives shareholder value? Paper Presented at the Federated Press' Creating Shareholder Value Conference, Toronto, Canada.

Daily, C., \& Dollinger, M. (1993). Alternative methodologies for identifying family versus non-family managed businesses. Journal of Small Business Management, 31(2), 79-90.

Egbunike, C., \& Okerekeoti, C. (2018). Macroeconomic factors, firm characteristics and financial performance: A study of selected manufacturing firms in Nigeria. Asian Journal of Accounting Research, 3(2), 142-168. doi:10.1108/ajar-09-20180029

Hamel, G., \& Prahalad, C. (1993). Strategy as stretch and leverage. Harvard Business Review, 71(2), 75-84. doi:10.1016/ S1471-7727(00)00002-6

Jorgensen, D. (1967). The theory of investment behaviour. Retrieved February 2, 2017, from www.economics.harvard. edu/faculty/jorgenson/complete_puhlications

Korankye, T., \& Adarquah, R. (2013). Empirical analysis of working capital management and its impact on the profitability of listed manufacturing firms in Ghana. Research Journal of Finance and Accounting, 4(1), 124-131.
Lall, S. (2001). Competitiveness, technology and skills. Cheltenham, UK: Edward Elgar Publishing.

Laitinen, E. (2008). Value drivers in finnish family-owned firms: Profitability, growth and risk. International Journal of Accounting and Finance, 1(1), 1-41.

Liargovas, P., \& Skandalis, K. (2008). Factors affecting competitiveness: The case of Greek industry. Retrieved June 16, 2016, from at www.lse.ac.uk/europeaninstitute/research.../ SKANDALIS_KONSTANTINOS.pdf

Lieberman, M., \& Balasubramanian, N. (2007June). Measuring value creation and its distribution among stakeholders of the firm. Paper Presented at the Academy of Management Annual Meeting, 2005 and the Atlanta Competitive Advantage Conference.

McConaughy, D., Matthews, C., \& Fialko, A. (2001). Founding family-controlled firms: Пerformance risk and value. Journal of Small Business Management, 39(1), 31-48. doi:10.1111/0447-2778.00004

Mouldi, D., Abdelaziz, H., \& Ilehmi, H. (2011). Single versus multiple bank relationships and firm performance: An econometric model for some Tunisian firms. International Research Journal of Finance and Economics, 63, 46-54.

Navaretti, B., Bugamelli, M., Schivadi, F., Altomonte, C., Horgos, D., \& Maggiani, D. (2011). The global operations of European firms. The Second EFIGE Policy Report. Bruesel Blueprint Series 12.

Odior, E. (2013). Macroeconomic variables and the productivity of the manufacturing sector in Nigeria: A static analysis approach. Journal of Emerging Issues in Economics, Finance and Banking, 1(5), 362-380.

Onakoya, A. (2018). Macroeconomic dynamics and the manufacturing output in Nigeria. Mediterranean Journal of Social Sciences, 9(2), 43-54. doi.org/10.2478/mjss-2018-0024

Onyemenam, C. (2004June). Firm Level Competitiveness in Nigeria. Paper presented at the ODI-NESG Seminar on Maximizing pro-poor growth: Regenerating the socioeconomic database in Nigeria held at the City University, Northampton Square, London, UK.

Porter, M. (1999). Microeconomics competitiveness: Findings from the 1999 executive survey. The Global Competitiveness Report. Geneva, Switzerland: World Economic Forum.

Porter, L., Lawler, E., \& Hackman, J. (1975). Behaviour in Organizations. New York, NY: McGraw-Hill. 
Prahalad, C., \& Hamel, G. (1990). The core competence of the Corporation. Harvard Business Review, 68(3), 79-91.

Samuel, J., Pulimi, M., Paul, M. L., Maurya, A., Natarajan Chandrasekaran, N., \& Mukherjee, A. (2013). Batch and continuous flow studies of adsorptive removal of $\mathrm{Cr}(\mathrm{VI})$ by adapted bacterial consortia immobilized in alginate beads. Bioresource Technology, 128, 423-430. doi.org/10.1016/j. biortech.2012.10.116
Shee, H. (2002). Competitiveness through Technological Excellence: A Case of Indian Software Industry. Doctoral Research, Department of Management Studies, IIT Delhi, India.

Smith, S. (1995). World class competitiveness. Managing Service Quality, 5(5), 36-42.

$$
\begin{array}{r}
\text { Received on } 17^{\text {th }} \text { March 2020, } \\
\text { after revision, } \\
\text { accepted for publication on } 17^{\text {th }} \text { August } 2020 . \\
\text { Published online on } 19^{\text {th }} \text { August } 2020 .
\end{array}
$$

Fatai Abiodun Atanda, $\mathrm{PhD}$ in Accounting, is a fellow of the Institute of Chartered Accountants of Nigeria. He is a lecturer at the Department of Accounting, University of Ibadan, Nigeria. His research interests are in the area of Sustainability Accounting, Corporate Financial Management and Small Business Development and Financing.

Olubunmi Florence Osemene, PhD in Accounting and Finance, is a fellow of the Institute of Chartered Accountants of Nigeria. He is an associate professor at the University of Ilorin, Nigeria. His research interests are in the area of Management Accounting and Environmental Accounting. 


\section{APPENDIX}

Table A1 The Box-Jenkins statistics for endogeneity (Correlogram) for all the firms (at the level)

\begin{tabular}{|c|c|c|c|c|c|c|}
\hline \multicolumn{7}{|l|}{ Sample: 19962017} \\
\hline \multicolumn{7}{|c|}{ Included observations: 1534} \\
\hline Autocorrelation & Partial Correlation & & $A C$ & PAC & Q-Stat & Prob \\
\hline$|* * * *|$ & $\left.\right|^{*} \mid$ & 1 & 0.494 & 0.199 & 809.09 & 0.000 \\
\hline $\mid * * *$ & |* & 2 & 0.443 & 0.136 & 1068.9 & 0.000 \\
\hline $\mid * * *$ & 1 & 3 & 0.369 & 0.030 & $1249 \cdot 3$ & 0.000 \\
\hline |** | & 1 & 4 & 0.318 & 0.024 & 1383.2 & 0.000 \\
\hline$|* *|$ & | 1 & 5 & 0.303 & 0.059 & 1504.8 & 0.000 \\
\hline |** | & 1 1 & 6 & 0.250 & -0.013 & 1587.6 & 0.000 \\
\hline$|* *|$ & 1 & 7 & 0.214 & -0.002 & 1648.5 & 0.000 \\
\hline$\left.\right|^{*} \mid$ & 1 & 8 & 0.200 & 0.021 & 1701.9 & 0.000 \\
\hline
\end{tabular}

Source: Authors

Table A2 The Box-Jenkins statistics for endogeneity (Correlogram) for the high-competition firms (at the level)

\begin{tabular}{|c|c|c|c|c|c|c|}
\hline \multirow{2}{*}{\multicolumn{7}{|c|}{$\begin{array}{l}\text { Sample: } 19962017 \\
\text { Included observations: } 769\end{array}$}} \\
\hline & & & & & & \\
\hline Autocorrelation & Partial Correlation & & $A C$ & PAC & Q-Stat & Prob \\
\hline.$|* * *|$ &.$^{*}$ & 1 & 0.431 & 0.106 & 527.08 & 0.000 \\
\hline$\left.\right|^{* *} \mid$ & . 1 & 2 & 0.345 & 0.008 & 606.44 & 0.000 \\
\hline.$|* *|$ &.$|. \quad|$ & 3 & 0.266 & -0.026 & 653.75 & 0.000 \\
\hline$.\left.\right|^{* *} \mid$ &. $\mid$ & 4 & 0.245 & 0.045 & 693.91 & 0.000 \\
\hline$.^{*} \quad \mid$ &. $\mid 1$ & 5 & 0.184 & -0.025 & 716.54 & 0.000 \\
\hline$.\left.\right|^{*} \quad \mid$ &.$|. \quad|$ & 6 & 0.166 & 0.025 & 735.06 & 0.000 \\
\hline $.1^{*} \quad \mid$ &.$|\quad|$ & 7 & 0.150 & 0.020 & 750.24 & 0.000 \\
\hline $.1^{*}$ & $.1 . \quad 1$ & 8 & 0.134 & 0.012 & 762.24 & 0.000 \\
\hline
\end{tabular}

Source: Authors

Table A3 The Box-Jenkins statistics for endogeneity (Correlogram) for the low-competition firms (at the level)

\begin{tabular}{|c|c|c|c|c|c|c|}
\hline \multicolumn{7}{|l|}{ Sample: 19962017} \\
\hline \multicolumn{7}{|c|}{ Included observations: 765} \\
\hline Autocorrelation & Partial Correlation & & $A C$ & PAC & Q-Stat & Prob \\
\hline.$\left.\right|^{* *}$ & $\left.\right|^{* *} \mid$ & 1 & 0.344 & 0.344 & 78.473 & 0.000 \\
\hline$.\left.\right|^{*} \mid$ &.$|. \quad|$ & 2 & 0.174 & 0.063 & 98.594 & 0.000 \\
\hline$. l^{*} \quad \mid$ &. $\mid$ & 3 & 0.123 & 0.051 & 108.58 & 0.000 \\
\hline.$|. \quad|$ &.$|. \quad|$ & 4 & 0.034 & -0.035 & $109 \cdot 34$ & 0.000 \\
\hline 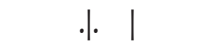 &.$|\quad|$ & 5 & 0.017 & 0.002 & 109.54 & 0.000 \\
\hline.$|. \quad|$ &.$|. \quad|$ & 6 & -0.020 & -0.033 & 109.81 & 0.000 \\
\hline $.1 . \quad 1$ & .|. 1 & 7 & -0.014 & 0.003 & 109.94 & 0.000 \\
\hline. $\mid$ &. $\mid$ & 8 & -0.038 & -0.033 & 110.89 & 0.000 \\
\hline
\end{tabular}

Source: Authors 


\title{
POKRETAČI KONKURENTNOSTI PREDUZEĆA U NEFINANSIJSKOM SEKTORU: PRIMER NIGERIJE
}

\author{
Fatai Abiodun Atanda' and Florence Olubunmi Osemene ${ }^{2}$ \\ ${ }^{1}$ Department of Accounting, University of Ibadan, Nigeria \\ ${ }^{2}$ Department of Accounting and Finance, University of Ilorin, Nigeria
}

U ovoj studiji se ispituju ključne determinante konkurentnosti preduzeća u Nigeriji. U studiji se izdvajaju podaci na nivou preduzeća (tj. karakteristike specifične za preduzeće) i makro-podaci (faktori okruženja) iz godišnjih izveštaja i računa nefinansijskih preduzeća koja se kotiraju na berzi i Statističkog biltena Centralne banke Nigerije, respektivno, koji se zatim analiziraju pomoću deskriptivnih, inferencijalnih i ekonometrijskih alatki. Dobijeni rezultati ukazuju na činjenicu da su starost preduzeća, njegova produktivna sredstva i profitabilnost, kao i racio vladinih kapitalnih izdataka, povećali konkurentnost izrazito konkurentnih preduzeća, s jedne strane, dok ju je, s druge strane, visok trošak finansiranja kočio. Međutim, profitabilnost, poslovni rizik, veličina preduzeća i inflacija su doprineli konkurentnosti slabo konkurentnih preduzeća, dok su je razvoj prodaje i kapacitet zaposlenih umanjili. Dolazi se do zaključka da su i faktori specifični za preduzeće i faktori okruženja odigrali i korisne i štetne uloge kada je u pitanju nivo konkurentnosti koji su ostvarila nefinansijska preduzeća kotirana na berzi u Nigeriji, zbog čega su i razmatrane implikacije tih rezultata na politiku preduzeća.

Ključne reči: izrazito konkurentno preduzeće, slabo konkurentno preduzeće, stvaranje vrednosti, faktor specifičan za preduzeće, faktor okruženja

JEL Classification: M41, G32 